\title{
Determinants of otolith chemistry: seasonal variation in the composition of blood plasma, endolymph and otoliths of bearded rock cod Pseudophycis barbatus
}

\author{
John M. Kalish* \\ Department of Zoology, University of Tasmania, GPO Box 252C, Hobart, Tasmania 7001, Australia
}

\begin{abstract}
Seasonal variation in the chemistry of bearded rock cod Pseudophycis barbatus plasma, endolymph and otoliths was investigated to determine the effects of physiology and environment on the trace element composition of otoliths. Cod blood, endolymph and otoliths were collected from freshly caught fish at sea. Quantities of protein, triglycerides, phosphate, glucose, calcium, sodium, potassium and strontium were determined in the blood plasma and the endolymph. These data, in conjunction with temperature data and basic biological information such as length, weight, sex, gonad weight, condition and age, were used to explain the levels of Sr found in cod otoliths. Using multiple regression models, it was possible to explain up to $98.5 \%$ of the total variance in female endolymph Sr levels on the basis of basic biological data and data on blood plasma chemistry. The results indicated that temperature does not directly affect the $\mathrm{Sr}, \mathrm{Na}, \mathrm{K}$ or $\mathrm{S}$ content of otoliths but, in adults, that changes in temperature are associated with major physiological changes, specifically the development of the gonads. These seasonal physiological changes are associated with changes in the chemistry of the blood plasma and the endolymph, which can result in differences in the trace element composition of otolith material. A brief investigation of the variability in the relative protein composition of the plasma indicated that there are large intraspecific and seasonal variations in protein complement, notably the albumins and globulins. These changes may ultimately affect the composition of endolymph and otoliths due to differences in metal-binding capacity. This is an area of potential further investigation. Data presented here show that the interpretation of otolith microchemistry data cannot be based on temperature data alone and that variations in otolith chemistry are due to the interaction of numerous factors. In the case of bearded rock cod, the negative correlation between temperature and otolith $\mathrm{Sr}$ is a fortuitous one, with changes in physiology being the major force. In other species changes in physiology similar to those observed here are likely to occur at very different times of the year Therefore, before the interpretation of otolith microchemistry data is undertaken, the researcher must carefully consider the various environmental and physiological factors unique to each species.
\end{abstract}

\section{INTRODUCTION}

The majority of research on fish otoliths has concentrated on what is essentially a by-product of their growth, specifically their time-keeping properties. The scientific literature dealing with the quantification of annuli and daily increments is extensive and seems to be increasing at an almost exponential rate. The concept of otoliths as recorders of physiological, environmental and life-history information is a logical extension of these time-keeping properties (Radtke 1984)

\footnotetext{
- Present address: MAF Fisheries Greta Point, PO Box 297. Wellington, New Zealand
}

and a similar rationale has resulted in an extensive literature on the chemistry of coral skeletons and molluscan shells.

Despite the promise of these ideas there are numerous problems in the interpretation of microchemical data derived from otoliths (Kalish 1989). The distribution of trace elements and isotopes within an otolith may be a manifestation of the combined effects of a fish's physiology, life-history stage and environment. The interpretation of otolith chemistry as the ultimate product of these factors is extremely complex and requires isolation of numerous physical and biological variables. Geochemical studies have made a large contribution to the understanding of the incorporation of 
trace elements into calcium carbonate (Reeder 1983); however, there is often difficulty in extending these concepts to biogenic carbonates. Few studies have considered the relationship between the chemisty of biogenic calcium carbonate and the chemistry of the precipitating fluid. Studies that have considered both the trace element chemistry of extrapallial fluid and the composition of bivalve shells are uncommon, but Lorens \& Bender (1980) showed a close relationship between them, as was found with fish endolymph $\mathrm{Sr}$ and otolith Sr (Kalish 1989). These studies, however, only considered the extrapallial fluid or endolymph composition in isolation and did not provide data on physical and biological factors that might influence the trace element composition of these fluids. I chose to address these and related problems by investigating seasonal variations in the composition of fish blood plasma, endolymph and otoliths.

Only a handful of studies have examined the composition of fish endolymph, and in only about one half of these studies were the investigators interested in endolymph composition in relation to the formation of otoliths. Enger (1964), Fänge et al. (1972), Watanabe \& Miyamoto (1973) and Mugiya \& Takahashi (1985) investigated the composition of fish endolymph to gain insight into the ionic composition of this fluid and the role of endolymph in the maintenance of saccular ionic potentials. Calcification studies by Mugiya (1964, 1966a, b) and Mugiya \& Takahashi (1985) remain the primary works on the relationship between fish endolymph composition and otolith calcification. These workers concentrated on aspects of endolymph composition that were particularly relevant to the seasonal formation of otolith opaque and hyaline zones and were primarily concerned with seasonal changes in the protein and calcium content of endolymph. Mugiya (1966b) determined seasonal changes in levels of magnesium in the endolymph and blood plasma of a salmonid, Oncorhynchus mykiss, and a flatfish, Kareius bicoloratus, but he did not relate these measurements to the composition of the otolith. Thus, only Kalish (1989) in a study of endolymph and otolith strontium. has related the trace element composition of fish endolymph to otolith composition.

The maintenance of internal composition, particularly of body fluids, is generally placed under the label of homeostasis. In cases where an element or metabolite is an essential component of some structure or required in a physiological process, the element or compound in question may be carefully regulated. It is clear that the chemistry of an organism will change depending on its physiological, reproductive or life history status, as well as on the season. The degree to which such changes are manifested in the blood plasma has been studied intensively in salmonids (Hille
1982); however, few studies have considered relationships in wild marine fish and, as indicated earlier, no studies have considered such interactions in endolymph. It seems likely that these physiological interactions are important in understanding changes in the plasma, endolymph and otoliths. Because of the complex nature of the interactions among the various constituents of an organism, the relationships are discussed in some detail to provide a framework for understanding the biology of the whole animal

This study sought to determine the relationships, if any, between ambient temperature, fish length, weight, sex, age, condition, gonad weight, the composition of blood plasma, endolymph and otoliths. The ultimate goal is to identify those factors that are most important in controlling the trace element composition of fish otoliths and to relate these data to seasonal variations in otolith trace element composition.

\section{MATERIALS AND METHODS}

Bearded rock cod Pseudophycis barbatus were selected for study because of their year-round availability and relative ease of capture, their large sagittal otoliths, and the associated large sacculus which contains adequate quantities of endolymphatic fluid for carrying out the required analyses without pooling fluid from more than one fish.

Collection of blood, endolymph and otoliths. Cod were collected from March 1987 to February 1988 by handline fishing over a rocky reef at depths of 20 to $25 \mathrm{~m}$ in Variety Bay, Tasmania. The number of fish collected each month is shown in Table 1 . Sample

Table 1. Pseudophycis barbatus. Number of bearded rock cod collected each month

\begin{tabular}{|lrcc|}
\hline Collection date & Males & Females & Total \\
\hline 25 Mar 1987 & 2 & 9 & 11 \\
17 Apr & 12 & 9 & 21 \\
22 Jun & 10 & 5 & 15 \\
29 Jul & 5 & 5 & 10 \\
8 Sep & 10 & 6 & 16 \\
19 Oct & 9 & 8 & 17 \\
6 Dec & 5 & 5 & 10 \\
8 Feb 1988 & 8 & 7 & 15 \\
\hline
\end{tabular}

collection was done at sea immediately after capture of individual fish. Within $30 \mathrm{~s}$ of being hooked fish were brought to the surface where they were killed by a blow to the head. Individuals were weighed to the nearest $10 \mathrm{~g}$ with a spring balance and the standard length measured. The tail was cut off in the region of the caudal peduncle for collection of blood from the 
dorsal aorta. Blood was collected by placing a capillary tube containing about 2 ul lithium heparin $10.25 \mathrm{mg}$ $\mathrm{ml}^{-1}$ ) against the dorsal aorta and collecting blood from the capillary tube in $1.5 \mathrm{ml}$ plastic centrifuge tubes. Korcock et al. (1988) have shown that blood collection from stunned specimens and the use of heparin result in the least change in parameters frequently measured in fish blood. Whole blood was placed on ice and centrifuged within $2 \mathrm{~h}$ of collection.

Endolymph was collected immediately after blood collection. Before exposing the brain, gill arches were cut and the fish was placed in seawater and agitated by hand for ca $30 \mathrm{~s}$ to ensure the removal of the greatest amount of blood possible. This step helped to eliminate problems of contamination of endolymph with blood. The brain was exposed and removed with forceps and any fluid remaining in the brain cavity was absorbed with lint-free paper making the sacculi containing the sagittal otoliths visible. The membrane between the brain cavity and the sacculus was punctured with the autopipette tip used for endolymph collection. In most cases, the otoliths were kept in place while the endolymph was removed with an autopipette with a standard low volume $(10$ to $250 \mu \mathrm{l})$ tip. When the otoliths obstructed most of the sacculus they were removed with plastic forceps before the endolymph was collected. Sample volume collected from individual fish ranged from 50 to $500 \mu \mathrm{l}$. Endolymph samples were stored in $0.5 \mathrm{ml}$ plastic centrifuge tubes. Immediately after collection the endolymph was placed on ice and subsequently stored at $4{ }^{\circ} \mathrm{C}$ prior to analysis. Analytical methods were similar for constituents of blood plasma and endolymph unless otherwise specified.

Only sagittal otoliths were collected in this study. Otoliths were extracted from the sacculus and the adhering otolith capsule was removed. Sagittae were rinsed in freshwater and then stored in individual glass vials.

Analysis of metabolites and ions. Inorganic phosphate levels were determined using the methods outlined by Daly \& Ertingshausen (1972), as modified by Wang et al. (1983). Acidified ammonium molybdate was added to ca $10 \mu \mathrm{l}$ of sample which resulted in the formation of phosphomolybdic acid. The quantity of phosphomolybdic acid was then determined by UV spectrophotometry at $340 \mathrm{~nm}$ and $30^{\circ} \mathrm{C}$.

Total triglycerides in plasma and endolymph were determined by the enzymatic hydrolysis of the triglycerides followed by the measurement of the resulting glycerol by spectrophotometry at $540 \mathrm{~nm}$ and $25^{\circ} \mathrm{C}$. The method is detailed by Wahlefeld (1974) and the reagents used were from a Boehringer Mannheim Diagnostic Kit (Triglycerides GPO-PAP).

Glucose was determined by the enzymatic method of
Bondar \& Mead (1974). Glucose was reacted with ATP and the enzyme hexokinase resulting in D-glucose6-phosphate which was reacted with glucose-6phosphate dehydrogenase in the presence of NAD (nicotinamide adenine dinucleotide). This resulted in the formation of reduced NAD (NADH) which was measured spectrophotometrically at $340 \mathrm{~nm}$. Reagents were from a Roche Diagnostic Kit (Glucose HK).

The majority of the protein assays were carried out using the protein-dye binding method of Bradford (1976) although some plasma protein analyses were done using the biuret assay (Kingsley 1939). The protein-dye binding method was used because of its greater sensitivity. This increased sensitivity was required to measure the low levels of protein in the endolymph. There were no significant differences in the results obtained using the 2 methods. The method of Bradford (1976) involves the binding of Coomasie Brilliant Blue G-250 to the protein which results in a shift in absorption maximum for the dye from 465 to $595 \mathrm{~nm}$.

Albumin was determined using the bromcresol green ( $\mathrm{BCG}$ ) binding assay, where the binding of albumin to $B C G$ results in a shift in the absorbance maxima of BCG (Doumas et al. 1971). The change in absorbance at $630 \mathrm{~nm}$ is proportional to the quantity of albumin in the sample. The reagent used was from an albumin test kit (Roche Reagents).

Strontium concentrations in endolymph and plasma samples were measured by graphite furnace atomic absorption spectrophotometry on a Varian AA-1475 spectrophotometer equipped with a GTA-95 graphite furnace and an autosampler. Argon was used as the purging gas in the graphite furnace. Samples were diluted up to 200 times with a $0.25 \%$ solution of an ionic detergent, Triton X-100, and $20 \mu \mathrm{l}$ of diluted sample were injected by autosampler into a walled, pyrolytically coated graphite tube. Furnace conditions were: drying at $90^{\circ} \mathrm{C}$ for $60 \mathrm{~s}$; ramp ashing from 90 to $700^{\circ} \mathrm{C}$ for $20 \mathrm{~s}$; ashing at $2600^{\circ} \mathrm{C}$ for $1 \mathrm{~s}$; and atomization, with no gas flow, at $2600^{\circ} \mathrm{C}$ for $3 \mathrm{~s}$. Based on initial results using the method of standard additions, there was no evidence of significant interferences in strontium analyses.

Plasma and endolymph calcium concentrations were determined by flame atomic absorption spectrophotometry using a nitrous oxide/acetylene flame. Potassium and sodium analyses were performed by atomic emission spectroscopy.

Two-way ANOVA was used to identify significant seasonal and sex-related variation in the physical and biological variables measured.

Characterization of plasma and endolymph proteins. Variations in serum proteins and comparison with endolymph proteins were carried out by electrophoresis on mylar-supported cellulosic media in a bar- 
bital-sodium barbital buffer of pH 8.6, ionic strength $0.06 \mathrm{M}$. Endolymph samples were concentrated before electrophoresis because of the low concentration of proteins in endolymph. Strips were stained with Ponceau $S$ and then rinsed in $5 \%$ acetic acid. The optical density of the electrophoresed proteins was measured in an automated densitometer which also plotted the optical density against the distance migrated by the proteins.

Estimation of the molecular weights and calcium binding capabilities of endolymph and plasma proteins was carried out by gel filtration on a $2.6 \times 30 \mathrm{~cm}$ column packed with Sephadex G-100 Fine gel filtration medium (Pharmacia, Uppsala, Sweden). Sample volumes were $1.5 \mathrm{ml}$ for both plasma and endolymph. The column was equilibrated and samples were run with $0.02 \mathrm{M}$ Tris- $\mathrm{HCl}$ buffer, $\mathrm{pH} 8.2$, containing $0.33 \mathrm{M}$ $\mathrm{NaCl}$. Flow rates through the column were maintained at ca $30 \mathrm{ml} \mathrm{h}^{-1}$ using a peristaltic pump. Continuous absorbance was measured at $280 \mathrm{~nm}$ and $1.5 \mathrm{ml}$ fractions were collected in an automated fraction collector. The gel column was calibrated using SDS Molecular Weight Markers (Sigma Chemical Company, St. Louis, MO, USA) and Blue Dextran. Calcium concentrations in the gel filtration fractions were determined by flame atomic absorption spectrophotometry using a nitrous oxide/acetylene flame.

Microprobe analysis of otoliths. Wavelength dispersive electron microprobe analysis was used to determine the concentrations of $\mathrm{Ca}, \mathrm{Sr}, \mathrm{Na}, \mathrm{K}$ and $\mathrm{S}$ in the marginal increments of the cod sagittae. Sample preparation was similar to that for blue grenadier otoliths as discussed in Kalish (1989). Analyses were done with a Cameca SX-50 wavelength dispersive electron microprobe. Microprobe analyses were carried out on transverse sections through the otolith primordium and a $10 \times 10$ um window (scanning raster) was employed. Beam current was $10 \mathrm{nA}$ measured on copper and the accelerating voltage was $15 \mathrm{kV}$. The crystal configuration, standards and counting procedures were similar to those employed for the analyses discussed in Kalish (1989). A minimum of 5 microprobe measurements were made at predetermined locations on the marginal increment of each transverse section. Results are presented as ratios of atomic concentrations.

Multiple regression models. Multiple regression models were investigated in an attempt to explain the variability in otolith and endolymph composition. Data on blood plasma, endolymph and otolith composition, fish length, weight, condition, reproductive state, age and water temperature were used to derive multiple regression models of the form:

$$
Y=a+b_{1} X_{1}+b_{2} X_{2}+\cdots+b_{n} X_{n}
$$

Multiple regression models were constructed using an interactive stepwise method with a significant $F$-statistic $(p \leq 0.05)$ as the major statistical criterion for inclusion in the model. Only those independent variables that were deemed biologically relevant and that would ultimately aid in the prediction of the dependent variable were considered. It was not believed appropriate, for example, to utilize a constituent of the endolymph to aid in the prediction of another endolymph variable. In such instances, it would be more appropriate to measure the dependent variable directly. Of course, the measurement of one endolymph variable might help to predict one or more dependent endolymph variables. Also, before consideration for inclusion in the model independent variables were plotted against dependent variables, along with the resultant standardized residuals and these plots were inspected to confirm that the assumptions of the regression analysis were not violated (Draper \& Smith 1981, Sokal \& Rohlf 1981). Where skewness was evident, a log transformation was applied to the independent variable data.

\section{RESULTS}

All cod were collected from a depth range of 20 to $25 \mathrm{~m}$ based on echo sounder readings. The seasonal variations in temperature and salinity at $20 \mathrm{~m}$ in Variety Bay (Fig. 1) are very similar to those measured at the surface and are indicative of a well-mixed system comprised of Tasman Sea surface waters and free of any major fresh water inputs due to runoff and precipitation or the effects of evaporation. These conditions were essential to ensure relatively constant water chemistry conditions at the collection site.

There were significant changes in both fish weight and length over the sampling period with fish of relatively constant size being collected from February to July after which there was a gradual increase in both weight and length for females and length only for

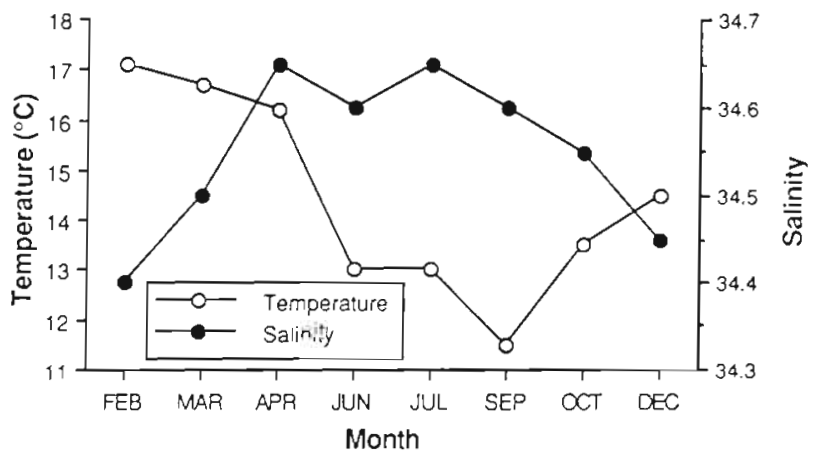

Fig. 1 Seasonal variation in temperature and salinity at $20 \mathrm{~m}$ in Variety Bay, Tasmania. Data were collected over the reef where Pseudophycis barbatus specimens were collected 

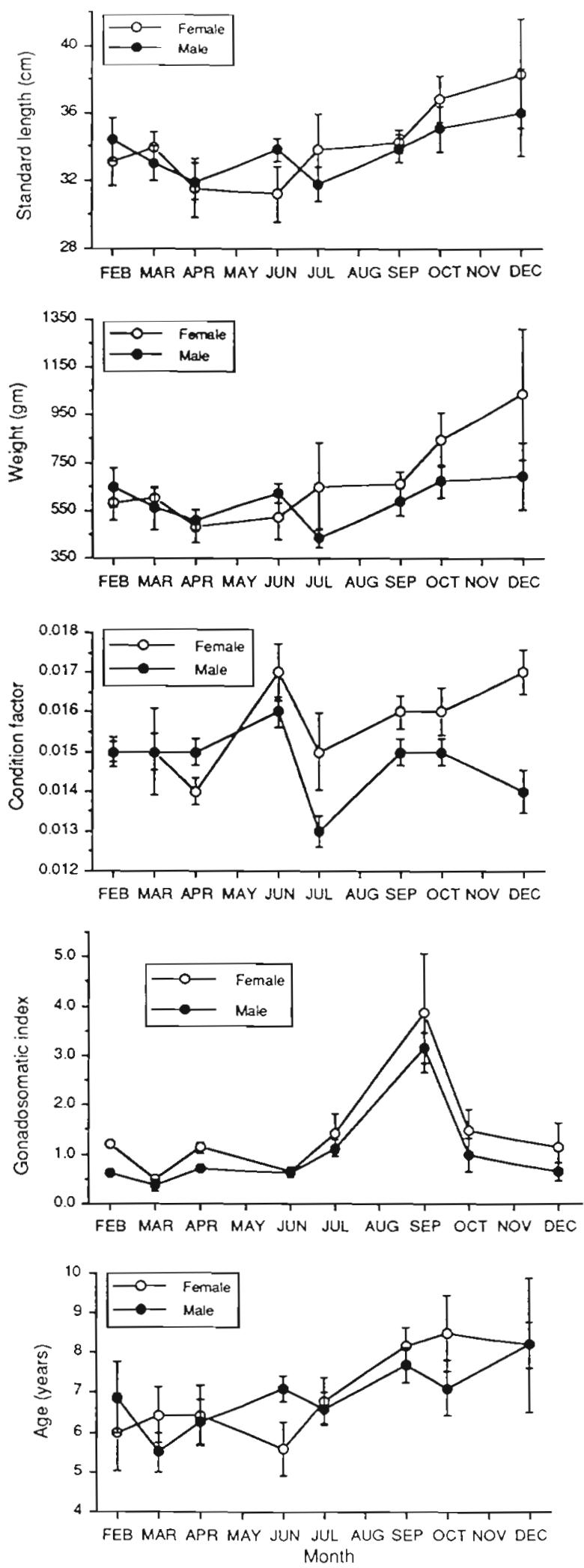

Fig. 2. Pseudophycis barbatus. Seasonal variation in standard length, weight, condition factor $\left(W / L^{3}\right)$, gonadosomatic index and age of cod collected from Variety Bay. Tasmania. Error bars are $\pm 1 \mathrm{SE}$ males (Fig. 2). Condition factor $\left(\mathrm{W} / \mathrm{L}^{3}\right)$ varied independently of the changes in the size of the fish collected over the year (Fig. 2). The decrease in condition in July was associated with an increase in gonad weight and gonadosomatic index indicating preparation for spawning (Fig. 2).

Otolith-based estimated ages of cod ranged from 3 to $14 \mathrm{yr}$ with significant changes in the mean age of fish collected over the sampling period (Fig. 2), but relationships among the chemical variables measured in the plasma, endolymph and otoliths and fish age were not significant. Therefore, it was not necessary to account for fish age when comparing data from different months as in an earlier study on blue grenadier (Kalish 1989).

\section{Plasma and endolymph metabolites}

A gradual increase in total plasma protein from February to June coincided with the June peak in condition factor in both males and females (Fig. 3). Male plasma protein decreased to the levels measured in February, while the female plasma protein remained stable from June to October. Both sexes showed the highest level of plasma protein, in December. Levels of total plasma proteins in males and females ranged from 21.0 to $61.7 \mathrm{~g} \mathrm{l}^{-1}$ and 18.6 to $54.6 \mathrm{~g} \mathrm{l}^{-1}$, respectively.

Total endolymph protein for both sexes ranged from 0.5 to $8.4 \mathrm{~g} \mathrm{l}^{-1}$, well below the levels measured in the plasma, and the seasonal pattern was different from that of total plasma protein (Fig. 3). Endolymph protein levels were at their lowest in February and March and, like plasma proteins, began to increase in April. However, the peak in endolymph protein was not reached until July in males and September in females. These peaks in endolymph protein may be related to the development of the gonads as indicated by the gonadosomatic index (Fig. 2).

There were no significant seasonal or sex-related variations in plasma glucose based on 2-way ANOVA and the interaction between these 2 sources of variation was not significant (Fig. 3). However, there were significant seasonal variations in glucose measured in the endolymph $(F=6.42, \mathrm{p}<0.0001)$. Both males and females showed an initial gradual increase in the level of endolymph glucose during March and April (Fig. 3). This gradual increase continued through September in the males but, in the females, there was a very sharp increase from July to September with peak levels being reached in September, coincident with the peak in gonadosomatic index. Endolymph glucose was both coincident and highly correlated with the gonadosomatic index (all fish, $\mathrm{r}^{2}=0.33, \mathrm{n}=115, \mathrm{p}<0.0001$; females only, $\left.\mathrm{r}^{2}=0.59, \mathrm{n}=54, \mathrm{p}<0.0001\right)$. 

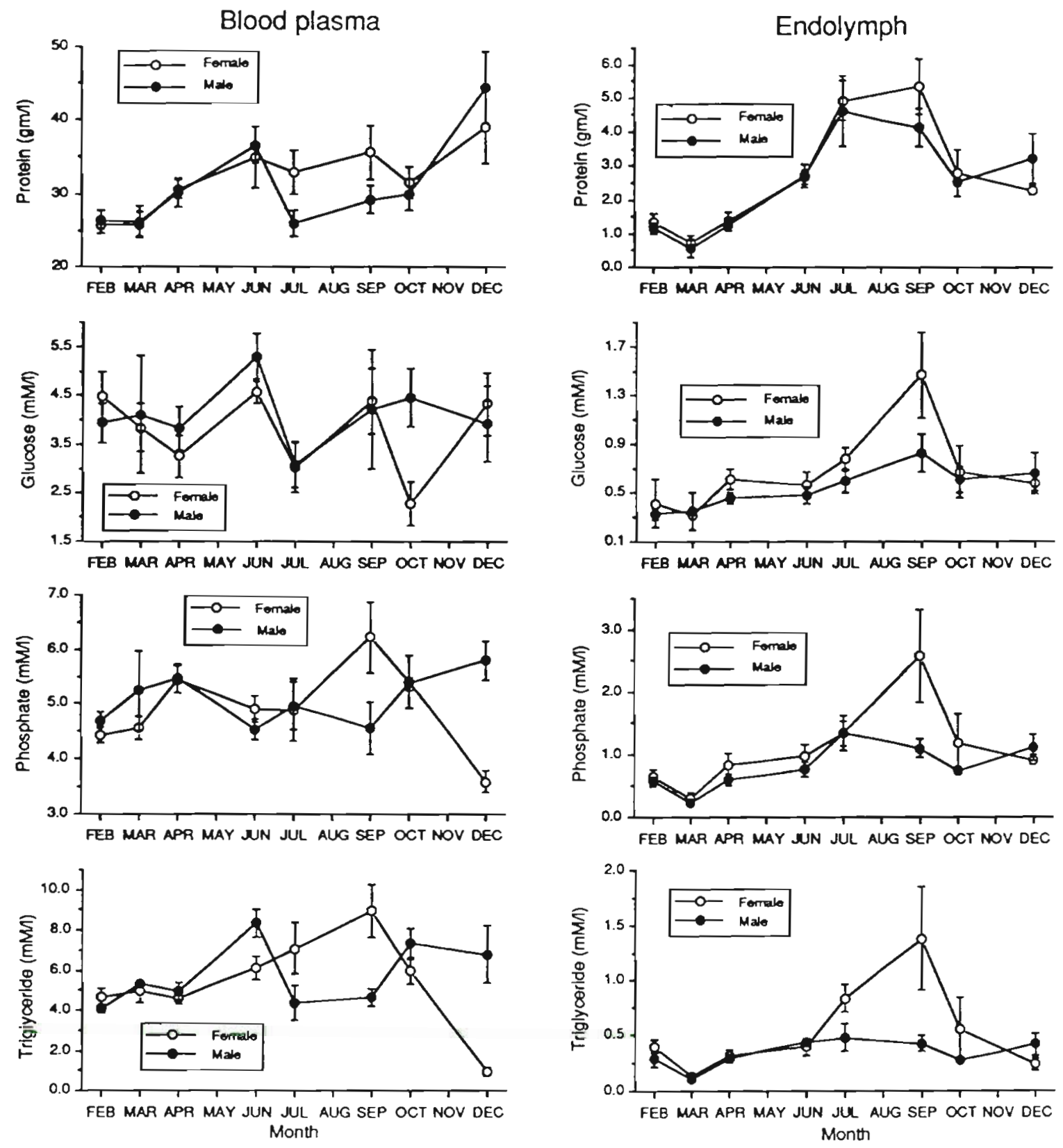

Fig. 3. Pseudophycis barbatus. Seasonal variation in protein, glucose, phosphate and triglycerides in the blood plasma (left) and endolymph (nght) of cod collected from Variety Bay, Tasmania. Error bars are $\pm 1 \mathrm{SE}$

Mean plasma glucose was more than 6 times the level measured in the endolymph. Despite the large differences in the mean endolymph glucose measured in September in males $\left(0.83 \mathrm{mM} \mathrm{l}^{-1}\right)$ and females $\left(1.47 \mathrm{mM} \mathrm{l}^{-1}\right)$ there was no significant difference detected among the sexes $(F=2.12, \mathrm{p}=1.00)$ or based on the interaction of month and $\operatorname{sex}(F=1.45, \mathrm{p}=0.19)$. This was probably due to the wide range of values obtained for males $\left(0.3\right.$ to $\left.1.7 \mathrm{mM} \mathrm{I}^{-1}\right)$ and females $(0.2$ to $2.3 \mathrm{mM} \mathrm{l}^{-1}$ ) during that month. Nevertheless, there was some evidence for a greater seasonal increase in glucose in females than in males.

Plasma phosphate levels varied significantly over the year $(F=2.35, p=0.03)$, but not by sex (Fig. 3). However, there was a significant interaction between month and sex $(F=3.90, \mathrm{p}=0.0009)$ indicating sexrelated differences in plasma phosphate over the year. Both males and females showed minor variations in plasma phosphate from February to July, but in September there was a sharp increase in the phosphate 
measured in the females. This rise was matched in the males by a more gradual increase in phosphate which peaks in December. However, during the period of increasing phosphate in the males, the females showed a decline to the lowest levels of the year in December.

Seasonal variations in endolymph phosphate (Fig. 3), most notably in the females, were very similar to the variations measured in endolymph glucose with peak values being reached in September. Males showed a gradual increase in endolymph phosphate from March to July, like glucose, but peak levels were reached 1 mo earlier. Endolymph phosphate and glucose were very highly correlated for both sexes $\left(\mathrm{r}^{2}=0.73, \mathrm{n}=115, \mathrm{p}<0.0001\right)$, and particularly in the females $\left(r^{2}=0.88, n=54, p<0.0001\right)$. Endolymph phosphate was also highly correlated with total protein in the endolymph $\left(\mathrm{r}^{2}=0.61, \mathrm{n}=115, \mathrm{p}<0.0001\right)$. Unlike endolymph glucose, there were significant variations among months $(F=5.94, \mathrm{p}<0.0001)$ as well as a significant interaction between months and sex $(F=$ $2.32, \mathrm{p}=0.03)$. The variation between sexes was not significant $(F=3.17, \mathrm{p}=0.07)$. Peak female plasma and endolymph phosphate levels are both reached in September.

Seasonal variations in plasma triglyceride levels were highly significant $(F=6.61, \mathrm{p}<0.0001)$ and followed a similar pattern to phosphate (Fig. 3). In females there was a gradual increase in triglycerides until the peak in September and a subsequent sharp decline to the lowest values of the year in December. The similarity of these 2 patterns was accentuated by the correlation between female plasma phosphate and triglyceride $\left(\mathrm{r}^{2}=0.34, \mathrm{n}=54, \mathrm{p}<0.01\right)$. There was a strong interaction between month and sex $(F=8.45$, $\mathrm{p}<0.0001$, the male pattern of variation being markedly different from that shown by the females. In males, triglycerides were constant from March to April, increased slightly in June, dropped to previous levels and increased again in October and December.

The seasonal pattern seen in endolymph glucose and phosphate was again apparent in endolymph triglyceride (Fig. 3). Seasonal ( $F=4.19, \mathrm{p}=0.0005)$, sexrelated $(F=4.23, \mathrm{p}=0.04)$ and interaction $(F=3.19$, $\mathrm{p}=0.0045)$ variations were all significant for the endolymph triglyceride data. Females showed a distinct peak in triglycerides in September and male levels showed no significant variation over the year. The endolymph triglyceride data were strongly correlated both with the glucose $\left(\mathrm{r}^{2}=0.61, \mathrm{n}=115\right.$, $p<0.0001)$ and the phosphate $\left(r^{2}=0.80, n=115\right.$, $p<0.0001$ ) data and, again, these correlations were strongest when the female data were considered separately $\left(r^{2}=0.78, n=54, p<0.0001\right.$ for glucose and $\mathrm{r}^{2}=0.87, \mathrm{n}=54, \mathrm{p}<0.0001$ for phosphate).

\section{Plasma and endolymph ions}

There were significant variations in plasma calcium by month $(F=5.98, \mathrm{p}<0.0001)$ and by $\operatorname{sex}(F=4.47$, $\mathrm{p}=0.035)$, but there was no significant interaction between these 2 variables $(F=0.32, p=0.94)$. The seasonal patterns shown by the 2 sexes were similar with a gradual decrease in plasma calcium from February to June, followed by a sharp increase from June to peak calcium levels in September/October (Fig. 4). Calcium levels declined in December to levels that were similar to those measured in February. Mean plasma calcium in females was $1.91 \pm 0.55 \mathrm{mM} \mathrm{l}^{-1}$ and $1.70 \pm 0.65 \mathrm{mM} \mathrm{l}^{-1}$ in males.

Endolymph calcium levels were significantly lower than plasma calcium levels (paired $t$-test, $t=8.28$, $\mathrm{n}=115, \mathrm{p}<0.0001)$ and showed different, but significant, seasonal variation $(F=4.56, \mathrm{p}=0.0002)$ (Fig. 4). The most notable point of the seasonal cycle in endolymph calcium was the peak in the females in September, coincident with the September peak in the gonadosomatic index. This peak was followed by a relatively sharp decline in endolymph calcium in both males and females. Variations between males and females and the interaction between month and sex were not significant.

Plasma sodium levels varied significantly through the year $(F=8.43, \mathrm{p}<0.0001)$, and showed evidence for 2 cycles during the year with peaks in June and September and troughs in March and December (Fig. 4). The seasonal cycles were very similar for both sexes as were the mean plasma sodium levels for males $\left(185 \pm 8 \mathrm{mM} \mathrm{l}^{-1}\right)$ and females $\left(183 \pm 8 \mathrm{mM} \mathrm{l}^{-1}\right)$. The significant seasonal variation of sodium in the endolymph $(F=4.20, \mathrm{p}=0.005)$ was very different from that measured in the plasma although males and females again showed similar patterns of variation (Fig. 4). Mean levels were ca $60 \%$ of that measured in the plasma.

Plasma and endolymph potassium varied significantly over the year ( $F=9.14, \mathrm{p}<0.0001$ for plasma and $F=2.41, \mathrm{p}=0.025$ for endolymph) and both showed the same general seasonal cycle (Fig. 4). Potassium levels reached their maximum in March and September and minimum in June and December and these cycles were similar for both sexes. Mean potassium levels were $7.10 \pm 1.83 \mathrm{mM} \mathrm{l}^{-1}$ and $67.15 \pm 5.76$ in the plasma and the endolymph, respectively. There was a significant correlation between endolymph $\mathrm{Na}$ and endolymph $\mathrm{K}\left(\mathrm{r}^{2}=0.36, \mathrm{n}=115, \mathrm{p}<0.001\right)$, but there was no such relationship in the blood plasma. This is probably due to the relative importance of $\mathrm{K}^{+}$and $\mathrm{Na}^{+}$ in maintaining ionic potentials in the sacculus as opposed to the blood.

Plasma strontium levels showed significant variation 


\section{Blood plasma}
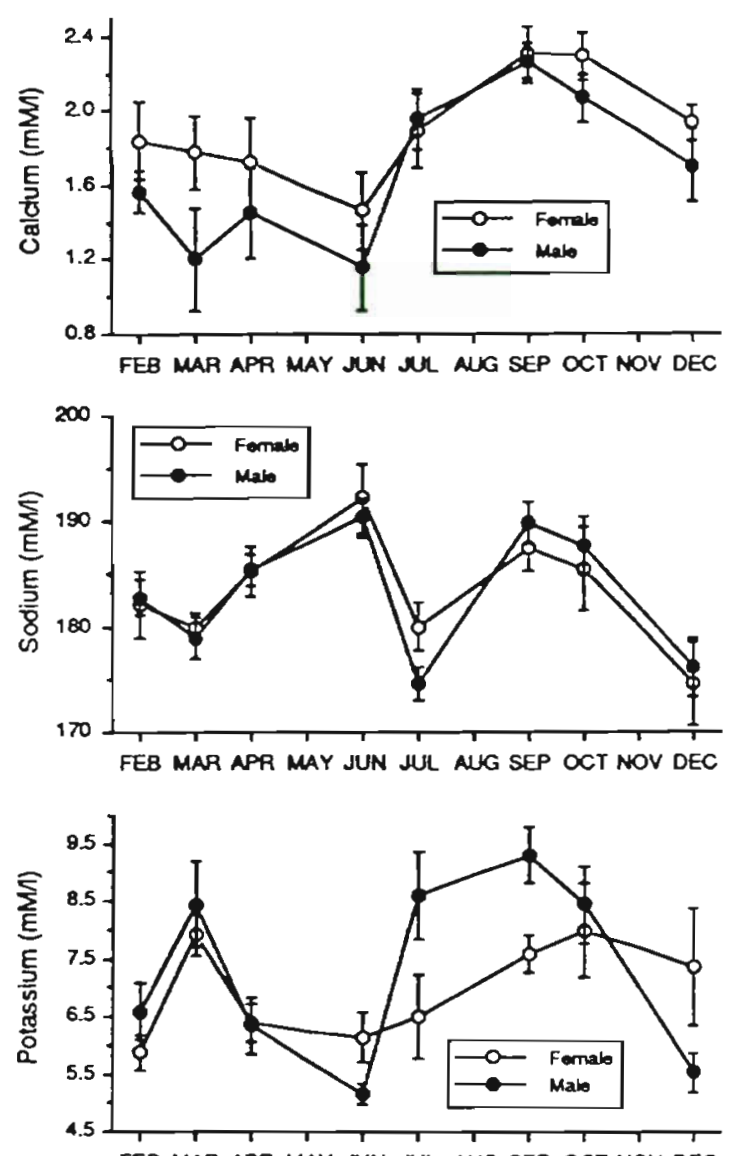

FEB MAR APF MAY UN IU AUG SEP OCT NOV DEC

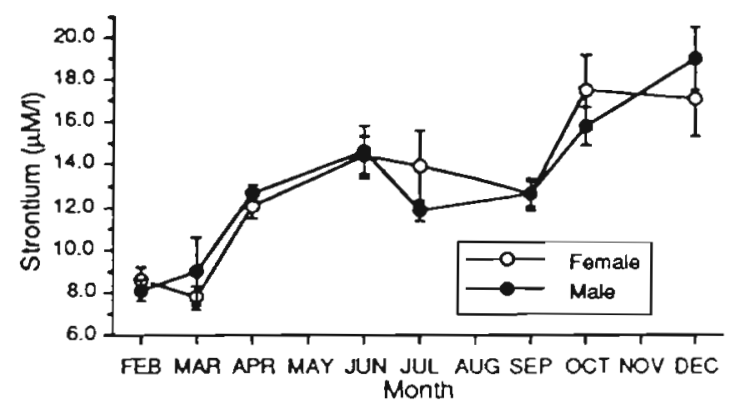

Endolymph
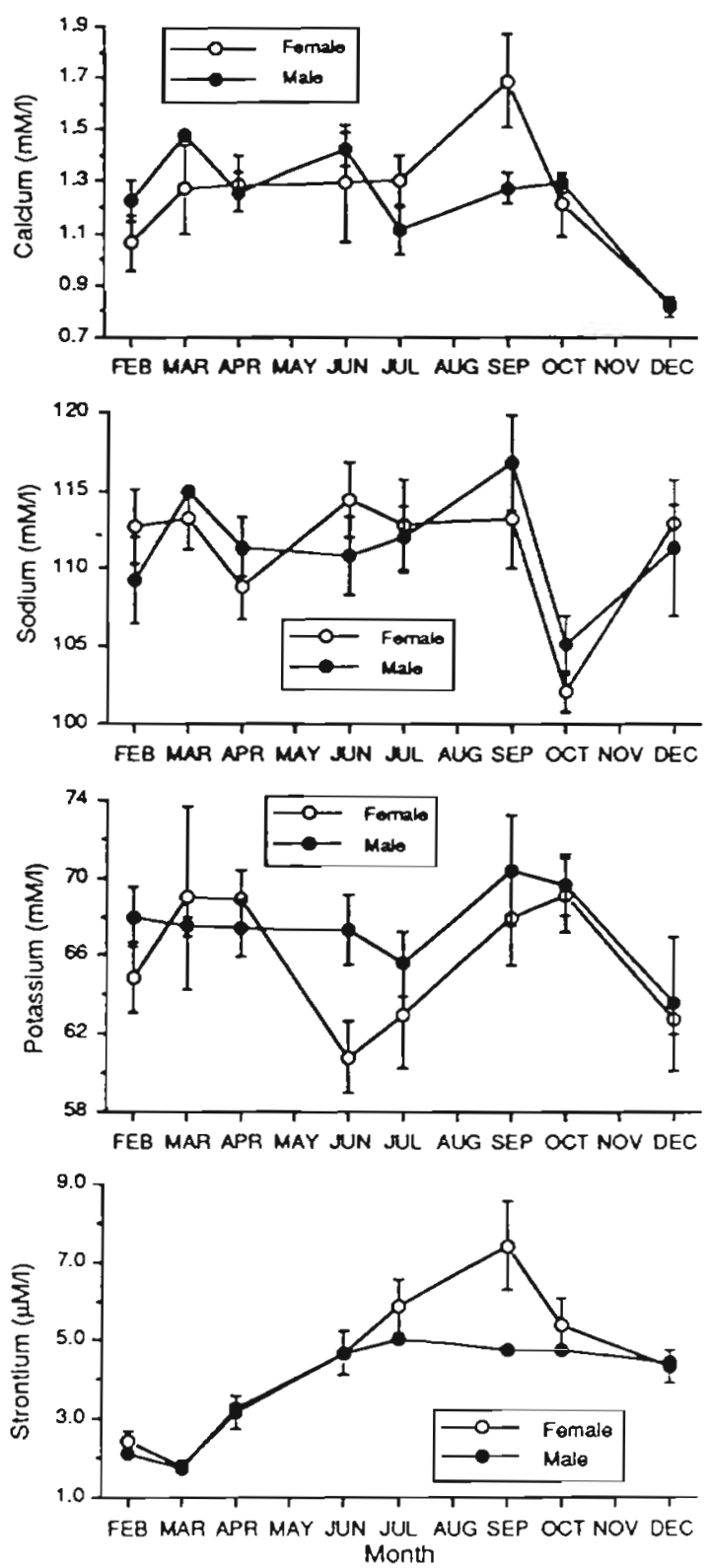

Fig. 4. Pseudophycis barbatus. Seasonal variation in calcium, sodium, potassium and strontium in the blood plasma (left) and endolymph (right) of cod collected from Variety Bay, Tasmania. Error bars are $\pm 1 \mathrm{SE}$

through the year $(F=22.37, \mathrm{p}<0.001)$, with little difference between the levels measured in males and females (Fig. 4). The data were somewhat unusual in that there was a large discrepancy between the February and December samples with mean strontium levels of $8.33 \pm 1.42$ and $18.05 \pm 3.65 \mu \mathrm{M} \mathrm{l}^{-1}$. For the present, it must be assumed that strontium levels fell relatively rapidly in December and January. Plots of the ratio of plasma strontium to plasma calcium over the year (Fig. 5A) showed even more pronounced cycles than when the elements were considered alone.
This was due to the fact that the relative increases and decreases in plasma strontium and calcium were opposing

Endolymph strontiurn showed significant seasonal variability $(F=17.44, p<0.0001)$ as well as a significant interaction between month and $\operatorname{sex}(F=2.12$, $p<0.04$ ). In females, strontium levels were similar in February and March, but increased almost monotonically from March to September (Fig. 4). Mean levels at the peak in September were $7.43 \pm 2.80 \mu \mathrm{M} \mathrm{l}^{-1}$, more than 4 times the mean level of $1.79 \pm 0.45 \mu \mathrm{M} \mathrm{l}^{-1}$ 

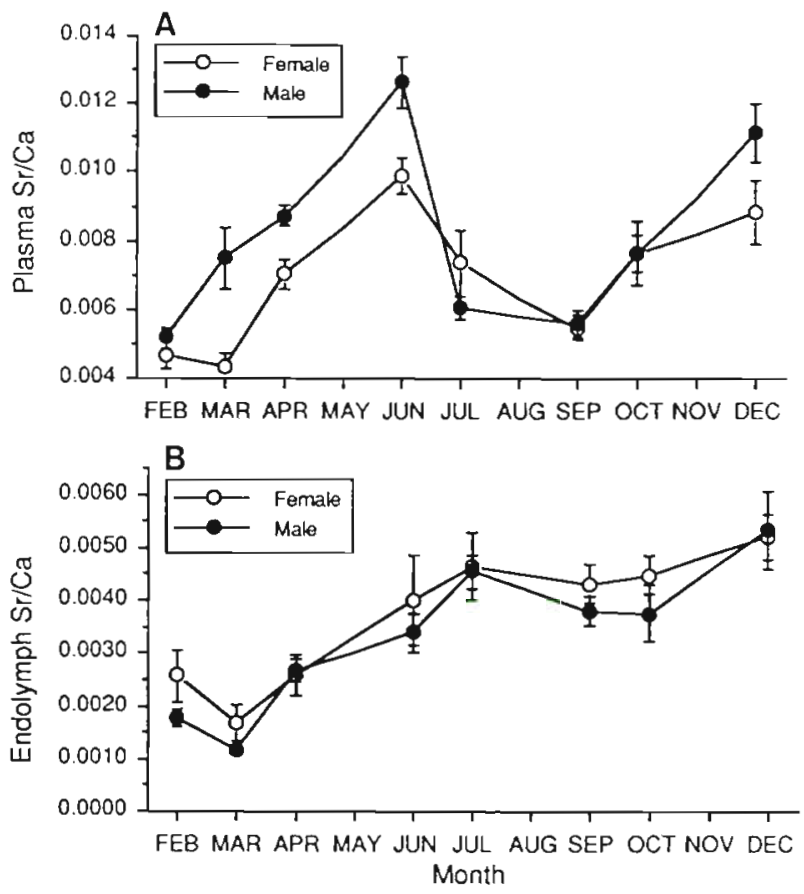

Fig. 5. Pseudophycis barbatus. Seasonal variation in (A) plasma $\mathrm{S} / \mathrm{Ca}$ ratio and (B) endolymph $\mathrm{Sr} / \mathrm{Ca}$ ratio in cod collected from Variety Bay, Tasmania. Error bars are $\pm 1 \mathrm{SE}$

measured in March. In males, the pattern of variation from February to June was almost identical to that of the females; however, unlike the females, there was virtually no change in endolymph strontium from June to December. Quantities of strontium in the male and female endolymph were almost identical in December.

Plots of the variation in endolymph $\mathrm{Sr} / \mathrm{Ca}$ ratio versus month (Fig. 5B) showed seasonal variation that was very similar to that of plasma strontium, and there was also a strong correlation between endolymph $\mathrm{Sr} / \mathrm{Ca}$ and plasma strontium $\left(r^{2}=0.36, n=115, p<0.0001\right)$ (Fig. 6A). This correlation was more significant than the correlation between endolymph $\mathrm{Sr}$ and plasma $\mathrm{Sr}$ $\left(r^{2}=0.26, n=115, p<0.0001\right)$ (Fig. 6B) due to the fact that the 4 female fish with very high endolymph strontium levels (>9.1 $\mu \mathrm{M} \mathrm{l}^{-1}$ ), seemingly independent of their plasma strontium level, also had relatively high plasma calcium $\left(>2.2 \mathrm{mM} \mathrm{l}^{-1}\right)$. Therefore, it is evident that, although the endolymph strontium level in cod is closely related to plasma strontium, other factors must clearly play a part in determining the quantity of strontium in the endolymph.

Endolymph strontium was strongly correlated with several other variables, particularly those indicative of the seasonal development of the female gonads before spawning. Correlations with gonad weight (all fish, $r^{2}=0.29, n=115, p<0.0001 ;$ females only, $r^{2}=0.39$, $\mathrm{n}=54, \mathrm{p}<0.001$ ) and gonadosomatic index, GSI (all fish, $\mathrm{r}^{2}=0.35, \mathrm{n}=115, \mathrm{p}<0.0001$; females only,
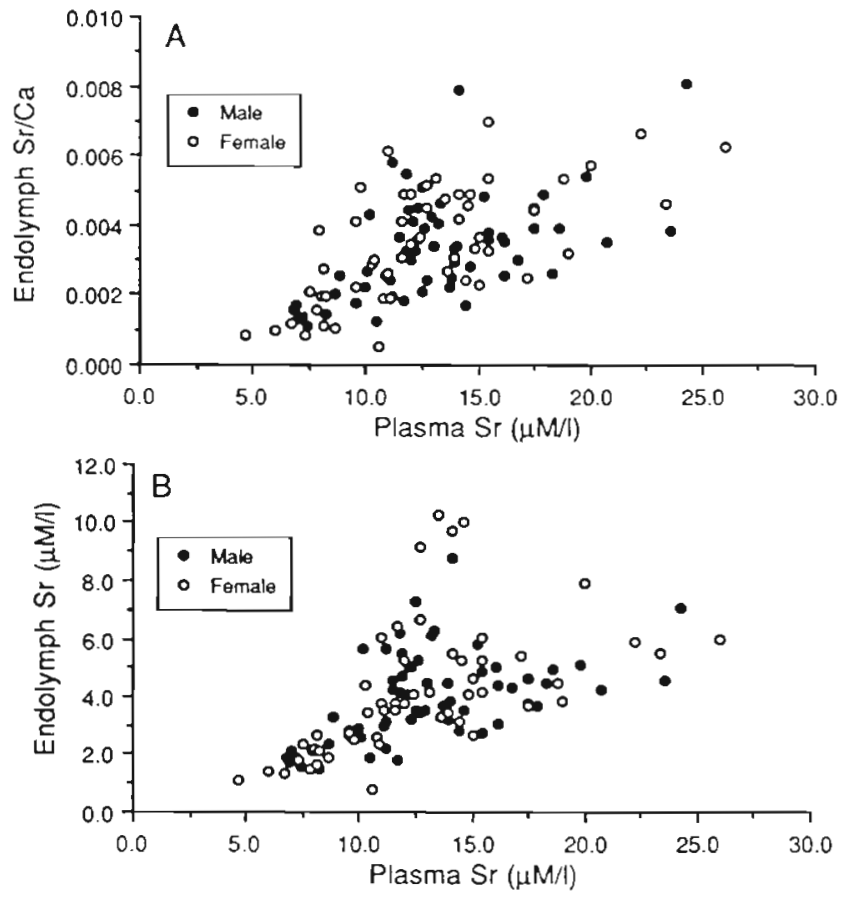

Fig. 6. Pseudophycis barbatus. Plots of (A) endolymph $\mathrm{Sr} / \mathrm{Ca}$ and $(B)$ endolymph $\mathrm{Sr}$ against plasma $\mathrm{Sr}$ in cod collected from

Variety Bay, Tasmania. Males, $\mathrm{n}=61$; females, $\mathrm{n}=54$

$\left.r^{2}=0.56, n=54, p<0.0001\right)$ were most notable. It is important to note that, while endolymph strontium was significantly correlated with GSI, there was no such correlation between plasma strontium and GSI (all fish, $\left.r^{2}=0.0003, n=115, p>0.5\right)$. There was also a strong negative correlation between endolymph strontium and temperature (all fish, $r^{2}=0.47, n=115, p<0.001$; females only, $r^{2}=0.59, n=54, p<0.001$ ) (Fig. 7), how-

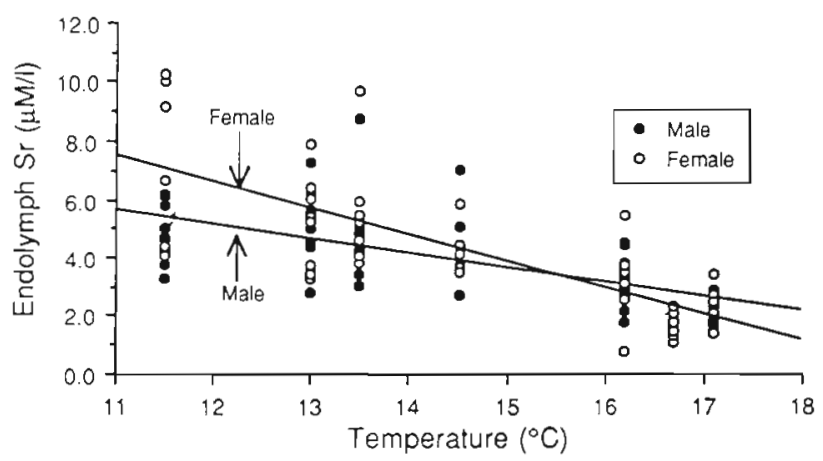

Fig. 7. Pseudophycis barbatus. Plot of endolymph Sr measured in cod collected from Variety Bay, Tasmania, against water temperature at $20 \mathrm{~m}$ at the point of capture. Although these variables were significantly correlated (all fish, $\mathrm{r}^{2}=0.47, \mathrm{n}=$ $115, p<0.001$ ) the relationship between these variables was not significant on the basis of Model 1 linear regression $(F=$ $3.03, \mathrm{df}=1,5, \mathrm{p}>0.10$ ). The lines based on linear regression, although not significant, are shown to clarify the positions of the endolymph $\mathrm{Sr}$ data, relative to temperature, attributable to the 2 sexes 
ever this relationship may be indirectly linked to the development of the gonads during the winter as will be discussed in a later section. There were also strong correlations between endolymph $\mathrm{Sr}$ and endolymph protein $\left(\mathrm{r}^{2}=0.57, \mathrm{n}=115, \mathrm{p}<0.0001\right)$, endolymph phosphorus $\left(\mathrm{r}^{2}=0.60, \mathrm{n}=115, \mathrm{p}<0.001\right)$ and endolymph glucose $\left(r^{2}=0.42, n=115, p<0.001\right)$.
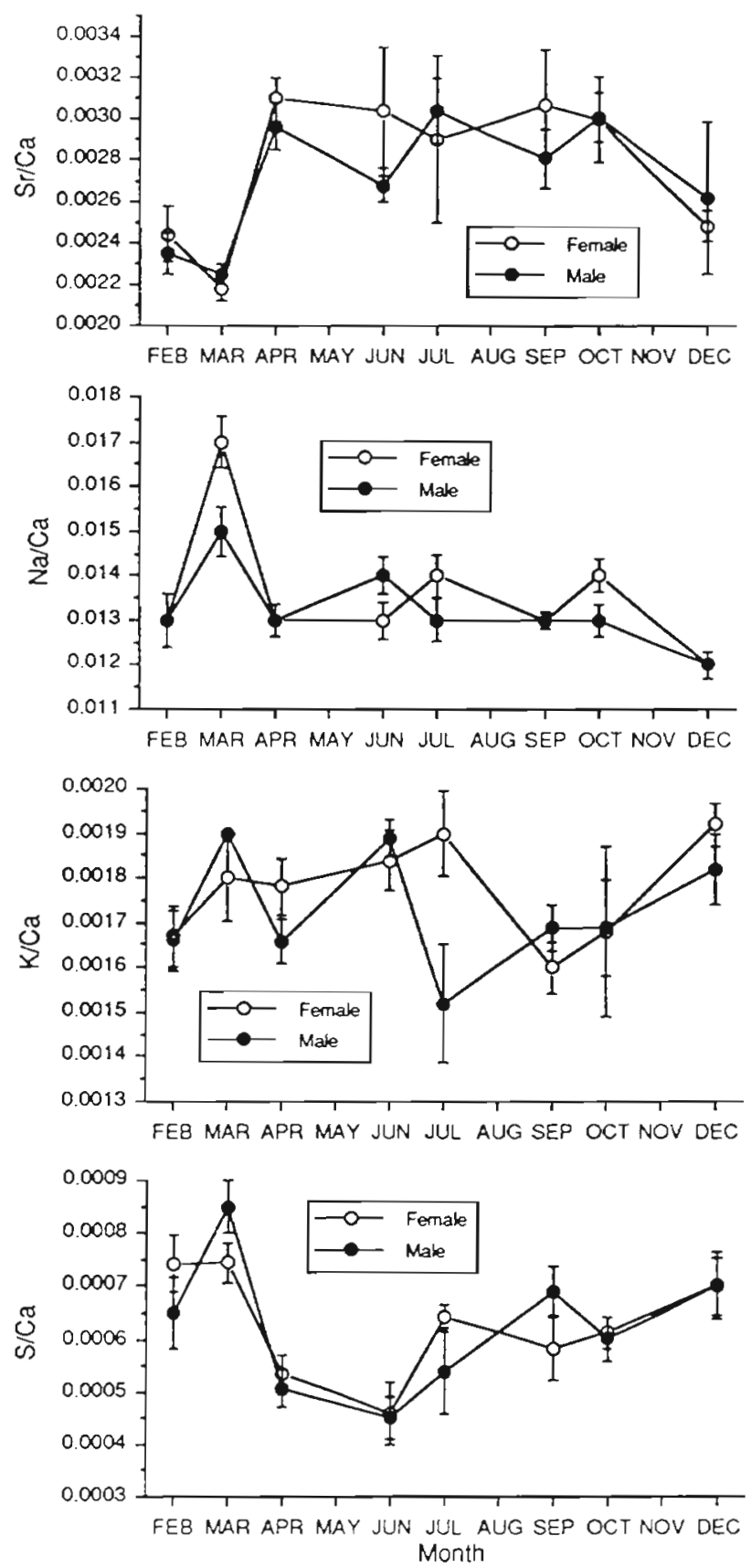

Fig. 8. Pseudophycis barbatus. Seasonal variation in otolith $\mathrm{Sr}$ $\mathrm{Ca}, \mathrm{Na} / \mathrm{Ca}, \mathrm{K} / \mathrm{Ca}$ and $\mathrm{S} / \mathrm{Ca}$ ratios, measured along the otolith margin by wavelength dispersive electron microprobe, in cod collected from Variety Bay, Tasmania. Error bars are $\pm 1 \mathrm{SE}$

\section{Otolith composition}

Measurements by wavelength dispersive electron microprobe of the composition of the cod otolith material formed previous to capture show that there were significant seasonal variations in otolith $\mathrm{Sr} / \mathrm{Ca}$ $(F=6.22, \mathrm{p}<0.0001), \mathrm{Na} / \mathrm{Ca} \quad(F=14.75, \mathrm{p}<0.0001)$, $\mathrm{K} / \mathrm{Ca}(F=2.42, \mathrm{p}=0.025)$ and $\mathrm{S} / \mathrm{Ca}(F=8.36$, $\mathrm{p}<0.0001$ ) ratios (Fig, 8). Only $\mathrm{Na} / \mathrm{Ca}$ ratios showed evidence of variability related to sex $(F=12.03$, $\mathrm{p}<0.0001)$. There was no indication of any significant interaction between month and sex for any of the chemical ratios measured.

Otolith Sr/Ca ratios showed one major cycle over the year with the lowest levels occurring in the summer months, Levels measured during the fall, winter and spring did not differ significantly. The otolith Sr/Ca data were positively correlated with the quantity of $\mathrm{Sr}$ measured in the endolymph $\left(\mathrm{r}^{2}=0.32, \mathrm{n}=115\right.$, $p<0.0001$ ) (Fig. 9), although the similarities between

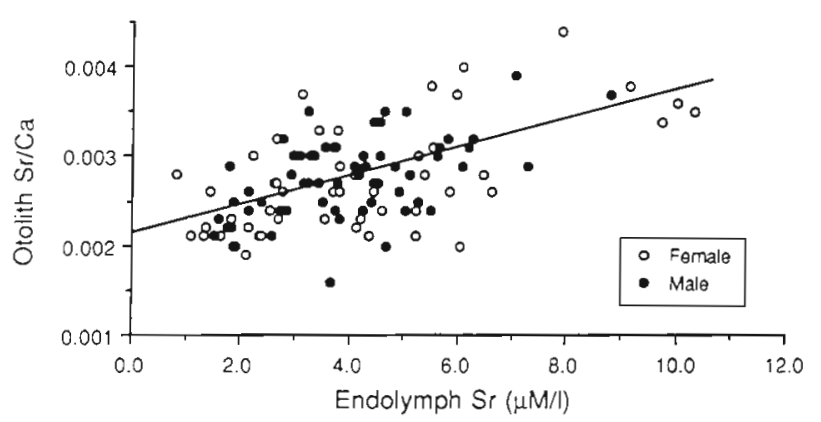

Fig. 9. Pseudophycis barbatus. Plot of otolith Sr/Ca ratio, measured along the otolith margin by wavelength dispersive electron microprobe, against endolymph $\mathrm{Sr}$ in cod collected from Variety Bay, Tasmania. Males, $\mathrm{n}=61$; females, $\mathrm{n}=54$

the seasonal changes exhibited by the 2 variables were very general with both showing relatively low levels in February and March and increasing to a plateau in the following months.

Variations in otolith $\mathrm{Na} / \mathrm{Ca}, \mathrm{K} / \mathrm{Ca}$ and $\mathrm{S} / \mathrm{Ca}$ were different from those exhibited by the Sr/Ca data. Otolith $\mathrm{Na} / \mathrm{Ca}$ showed a distinct peak in March in both sexes, but was relatively constant throughout the rest of the sampling period (Fig. 8). K/Ca data showed greater variability with the most notable feature being a drop in otolith $\mathrm{K} / \mathrm{Ca}$ in the winter (July in males and September in females) that gradually returned to higher levels in the spring and early summer. Otolith S/Ca data showed a relatively distinct single seasonal cycle which was similar for both sexes (Fig 8). There was a peak in S/Ca during the summer followed by a sharp decline in the fall to a minimum in June. The S/Ca ratio gradually increased during the latter part of winter and spring, finally returning to the peak summer levels. 


\section{Multiple regression models of strontium in endolymph and otoliths}

Numerous significant correlations were found among endolymph and otolith Sr data and the environmental and physiological variables (Table 2). Although the most significant correlations with endolymph Sr were other endolymph variables, these data were not considered in the models for reasons discussed earlier. Furthermore, endolymph variables such as protein, glucose, calcium, phosphate and triglycerides were all highly correlated with GSI, a variable considered for inclusion in the endolymph Sr models.

Multiple linear regression models were clearly more effective at explaining the variation in endolymph $\mathrm{Sr}$ measured in female than male fish. Details of the variables included in the models are shown in Table 3. A model containing 3 variables (temperature, GSI and plasma Sr) was able to explain $84 \%$ of the variance in the endolymph Sr data from female cod, whereas a multiple regression model, also containing 3 variables (temperature, plasma $\mathrm{Sr}$ and plasma $\mathrm{Ca}$ ) could only explain $49 \%$ of the variance in male endolymph Sr data. When both sexes were combined the multiple regression model included 5 variables (temperature, gonad weight, plasma Sr, fish weight and plasma $\mathrm{K}$ ) and explained $69 \%$ of the variance in the data. All 3 models involved ambient temperature and plasma Sr.
Like the endolymph Sr models, the otolith Sr multiple linear regression models were more effective at explaining the variance in the female cod (Table 4). A model containing 6 variables (fish length, GSI, plasma Sr, plasma $\mathrm{Ca}$, condition factor and age) explained $69 \%$ of the variance in the female cod otolith Sr data. The best model for male otolith Sr data explained only $44 \%$ of the variance and contained 3 variables (fish weight, endolymph $\mathrm{Sr}$ and endolymph protein). A model to predict otolith $\mathrm{Sr}$ in both males and females was marginally better than the model for males and explained $52 \%$ of the variance with 6 variables (fish weight, gonad weight, endolymph Sr, plasma Sr, endolymph protein and condition factor).

\section{Characterization of plasma and endolymph proteins}

Results of cellulose acetate electrophoresis showed that there were large differences in the relative protein composition of cod plasma over the year and somewhat smaller differences within samples from the same collecting trip. These differences were evident in the electrophoretic patterns of fish plasma and in the elution diagrams derived from the electrophoretic data (Fig. 10). Individual elution diagrams are explained in the appropriate figure captions. Evidence of the potential variation in the calcium-binding capacity of fish plasma from various individuals can be realized by

Table 2. Pseudophycis barbatus. Correlation coefficients for physiological and environmental variables significantly correlated $(\mathrm{p}<0.05)$ with endolymph and otolith strontium variables. (Total $\mathrm{n}=115 ;$ females, $\mathrm{n}=54 ;$ males, $\mathrm{n}=61$ )

\begin{tabular}{|c|c|c|c|c|c|c|}
\hline \multirow[t]{2}{*}{ Variable } & \multicolumn{3}{|c|}{ Endolymph Sr } & \multicolumn{3}{|c|}{ Otolith Sr/Ca } \\
\hline & Females & Males & Both sexes & Females & Males & Both sexes \\
\hline Temperature & -0.768 & -0.635 & -0.685 & -0.38 & & -0.295 \\
\hline Length & & & & -0.281 & & -0.265 \\
\hline Weight & & & & -0.267 & -0.295 & -0.275 \\
\hline Condition factor & & & & & -0.261 & -0.234 \\
\hline Age & & & 0.234 & & & \\
\hline Gonad weight & 0.623 & 0.337 & 0.538 & 0.263 & & 0.19 \\
\hline GSI & 0.745 & 0.31 & 0.589 & 0.467 & & 0.329 \\
\hline Plasma protein & 0.533 & & 0.312 & & & \\
\hline Plasma Sr & 0.549 & 0.474 & 0.512 & 0.547 & 0.363 & 0.468 \\
\hline Plasma Ca & 0.296 & 0.393 & 0.329 & & & \\
\hline Plasma Na & & & & 0.285 & & \\
\hline \multicolumn{7}{|l|}{ Plasma K } \\
\hline \multicolumn{7}{|l|}{ Plasma glucose } \\
\hline Plasma triglyceride & 0.574 & & 0.377 & 0.36 & & 0.215 \\
\hline Plasma phosphate & 0.338 & & 0.231 & 0.371 & & 0.272 \\
\hline Endolymph protein & 0.823 & 0.673 & 0.754 & 0.48 & & 0.327 \\
\hline Endolymph Sr & 1.00 & 1.00 & 1.00 & 0.583 & 0.534 & 0.562 \\
\hline Endolymph Ca & 0.388 & & 0.263 & & & \\
\hline Endolymph $\mathrm{Na}$ & & 0.284 & & & & \\
\hline \multicolumn{7}{|l|}{ Endolymph $\mathrm{K}$} \\
\hline Endolymph glucose & 0.734 & 0.377 & 0.616 & 0.456 & & 0.319 \\
\hline Endolymph triglyceride & 0.80 & 0.42 & 0.692 & 0.478 & & 0.347 \\
\hline Endolymph phosphate & 0.793 & 0.547 & 0.718 & 0.52 & & 0.391 \\
\hline
\end{tabular}


Table 3. Pseudophycis barbatus. Multiple linear regression model coefficients and associated statistics for estimation of endolymph $\mathrm{Sr}\left(\mathrm{mM} \mathrm{l}^{-1}\right)$

\begin{tabular}{lccc}
\hline Variable & Coefficient & SE & p \\
\hline Females $(\mathrm{n}=51$ ) & & & $<0.0001$ \\
Temperature & -0.00045 & $8.43 \times 10^{-5}$ & $<0.0001$ \\
GSI & 0.001 & $9.55 \times 10^{-5}$ & $<0.0001$ \\
Plasma Sr & 0.142 & 0.034 & \\
Constant (a) & 0.008 & & $<0.0001$ \\
Multiple correlation, $\mathrm{R}=0.917$ & & & $<0.005$ \\
Males (n $=64)$ & & $8.01 \times 10^{-5}$ & $<0.025$ \\
Temperature & -0.00036 & 0.039 & \\
Plasma Sr & 0.117 & 0.000224 & \\
Plasma Ca & 0.001 & & $<0.0001$ \\
Constant (a) & 0.007 & & $<0.0001$ \\
Multiple correlation, $\mathrm{R}=0.703$ & & & $<0.0001$ \\
Both sexes ( $\mathrm{n}=115)$ & & $6.52 \times 10^{-5}$ & $<0.0001$ \\
Temperature & -0.00038 & $4.81 \times 10^{-7}$ & $<0.01$ \\
Fish weight & $-2.08 \times 10^{-6}$ & $1.22 \times 10^{-5}$ & \\
Gonad weight & $9.71 \times 10^{-5}$ & 0.028 & \\
Plasma Sr & 0.152 & $5.74 \times 10^{-5}$ & \\
Plasma K & -0.00016 & & \\
Constant (a) & 0.009 & & \\
Multiple correlation, $\mathrm{R}=0.832$ & & & \\
\hline
\end{tabular}

Table 4. Pseudophycis barbatus. Multiple linear regression model coefficients and associated statistics for estimation of otolith $\mathrm{Sr} / \mathrm{Ca}$ ratios

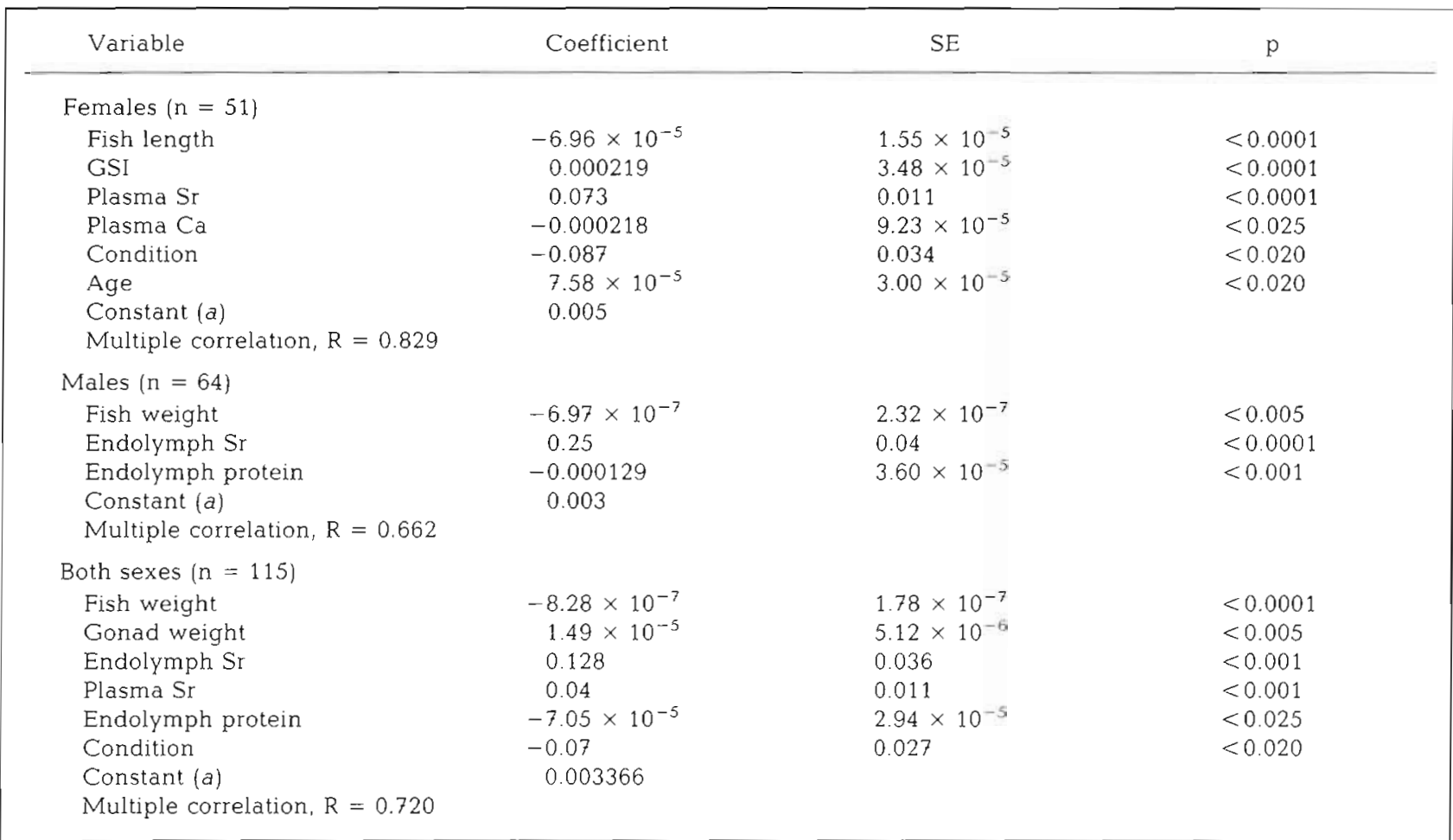

examination of the differences in the quantities of the albumin and globulin fractions in the plasma and, the albumin/globulin ratio ( $\mathrm{A} / \mathrm{G}$ ratio) derived from the elution diagrams. Spectrophotometric measurement of albumin in the plasma samples also highlighted the variability of these data (Table 5).

As with other physiological data, the blood protein data appeared to be more useful in investigations of 

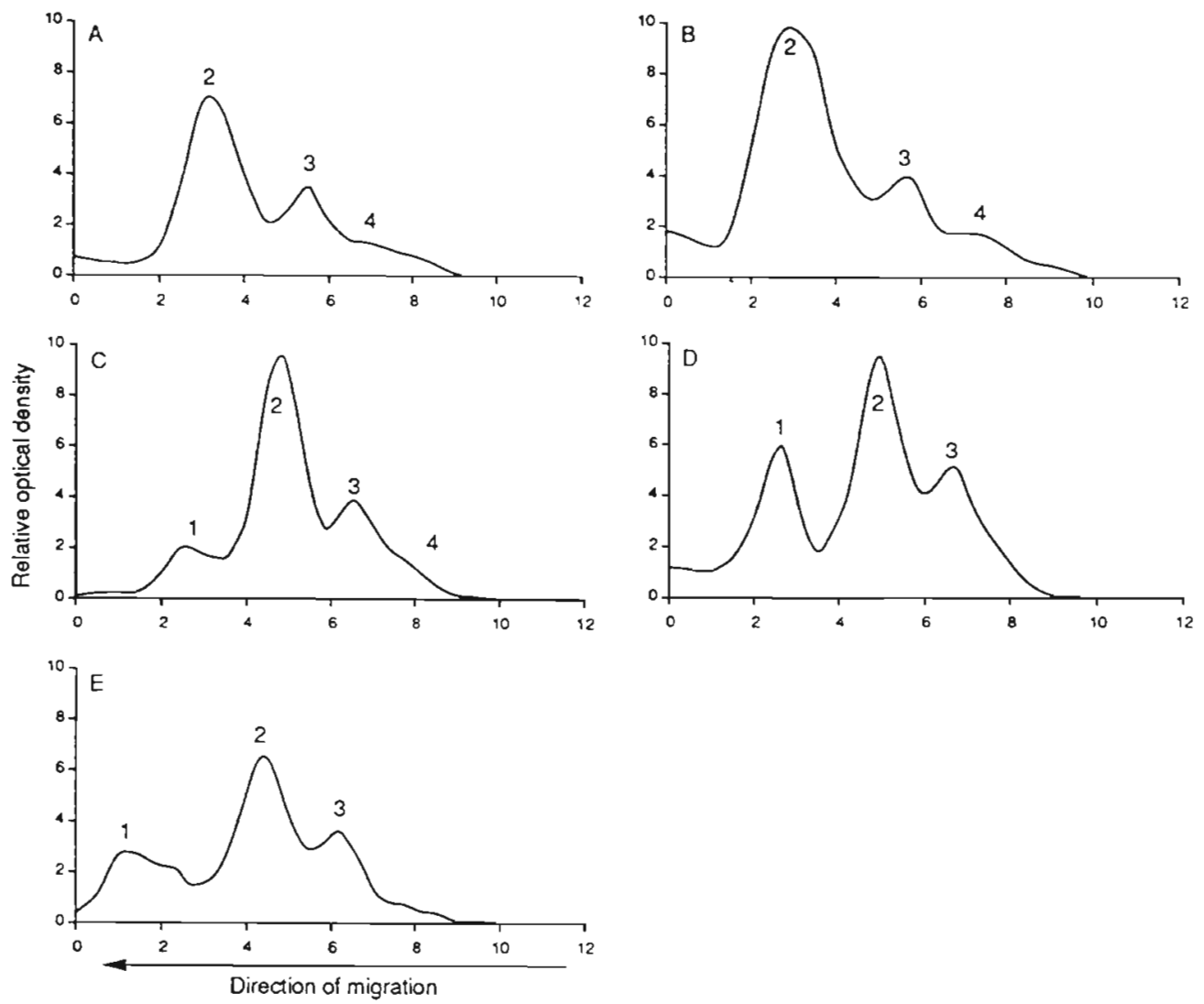

Fig. 10. Pseudophycis barbatus. Elution diagrams derived from electrophoretic data of blood plasma and endolymph. The direction of migration is from right to left. Fractions are labelled as follows: $1=$ prealbumin; $2=$ albumin; $3=\alpha$ globulin and $\beta$ globulin; $4=\gamma$ globulin. (A) to (D) are derived from blood plasma. (A) Collected April, male, $35 \mathrm{~cm} \mathrm{SL,} \mathrm{A/G} \mathrm{ratio}=1.61$; (B) collected June, male, $34 \mathrm{~cm} \mathrm{SL}, \mathrm{A} / \mathrm{G}$ ratio $=3.35$; (C) collected December, male, $46 \mathrm{~cm} \mathrm{SL}, \mathrm{A} / \mathrm{G}$ ratio $=1.20$; (D) collected December, female, $37 \mathrm{~cm} \mathrm{SL}, \mathrm{A} / \mathrm{G}$ ratio $=0.81$. (E) Derived from endolymph pooled from 5 cod collected in December. Fractions are labelled as in (A) to (D), but these fractions may be somewhat different from those found in the blood plasma

variations in the chemical makeup of the female cod. Only a fraction of the cod samples were analysed electrophoretically (27 of 115 samples). In female fish the ratio of albumin to globulins $(\mathrm{A} / \mathrm{G})$ was negatively correlated with temperature $\left(\mathrm{r}^{2}=0.35, \mathrm{n}=14, \mathrm{p}=\right.$ $0.033)$, and positively correlated with plasma triglycerides $\left(r^{2}=0.38, n=14, p=0.025\right)$. Plasma albumin was negatively correlated with temperature $\left(r^{2}=0.43\right.$, $\mathrm{n}=14, \mathrm{p}=0.011)$ and positively correlated with endolymph Sr $\left(r^{2}=0.58, n=14, p=0.002\right)$, GSI $\left(r^{2}=\right.$ $0.59, n=14, p<0.001)$, plasma triglycerides $\left(r^{2}=0.58\right.$, $\mathrm{n}=14, \mathrm{p}=0.002)$, endolymph protein $\left(\mathrm{r}^{2}=0.55, \mathrm{n}=14\right.$, $\mathrm{p}=0.003)$, endolymph glucose $\left(\mathrm{r}^{2}=0.46, \mathrm{n}=14, \mathrm{p}=\right.$ $0.008)$, endolymph calcium $\left(r^{2}=0.29, n=14, p=0.05\right)$, endolymph phosphate $\left(r^{2}=0.61, n=14, p<0.001\right)$ and endolymph triglycerides $\left(r^{2}=0.67, n=14, p=0.0004\right)$. These variables were not significantly correlated in the male fish. Incorporation of the variable $\mathrm{A} / \mathrm{G}$ ratio into a multiple regression model to predict the endolymph $\mathrm{Sr}$ made it possible to explain $98.5 \%$ of the total variance in female endolymph Sr levels (Table 6). The model included the variables $A / G$ ratio, plasma protein, fish length, fish weight, gonad index and plasma Sr.
Cellulose acetate electrophoresis of concentrated cod endolymph indicated that the gross protein composition of endolymph was not greatly different from that found for the plasma (Fig. 10). As in a majority of the plasma samples, there were large prealbumin and albumin fractions. Other fractions, presumably globulins, were not well separated.

Gel filtration of cod plasma and endolymph and subsequent calcium analyses of the fractions indicated that both the relative distribution of proteins as well as the calcium-binding fractions were not grossly different (Fig. 11). There was no evidence for a unique calcium-binding protein in the endolymph, but this could be an artefact of the relative insensitivity of the separation procedure employed at certain molecular weights. Also, there was some difficulty in accurately determining calcium concentrations due to excessively high background levels in the samples when analysing the fractions by atomic absorption spectrophotometry. These protein separation trials were largely exploratory and serve to highlight the utility of these techniques.

Calcium binding occurred in similar molecular 
Table 5. Pseudophycis barbatus. Total plasma protein, albumin and albumin/globulin (A/G) ratio data from selected cod

\begin{tabular}{|c|c|c|c|c|}
\hline $\begin{array}{l}\text { Collection } \\
\text { date (1987) }\end{array}$ & Sex & $A / G$ & $\begin{array}{l}\text { Albumin } \\
\left(g \mathrm{I}^{-}\right)\end{array}$ & $\begin{array}{c}\text { Protein } \\
\left(\mathrm{g} \mathrm{l}^{-}\right)\end{array}$ \\
\hline $17 \mathrm{Apr}$ & $M$ & 1.16 & 15 & 37.4 \\
\hline $17 \mathrm{Apr}$ & M & 1.61 & 13 & 32.7 \\
\hline $17 \mathrm{Apr}$ & F & 1.54 & 8 & 24.0 \\
\hline $17 \mathrm{Apr}$ & $F$ & 0.77 & 11 & 36.4 \\
\hline 22 Jun & M & 1.50 & 10 & 26.5 \\
\hline 22 Jun & M & 3.35 & 11 & 41.3 \\
\hline 22 Jun & F & 1.17 & 13 & $\cdot 35.2$ \\
\hline 22 Jun & F & 1.25 & 10 & 50.5 \\
\hline $29 \mathrm{Jul}$ & $M$ & 1.79 & 11 & 32.4 \\
\hline $29 \mathrm{Jul}$ & $F$ & 2.84 & 12 & 41.0 \\
\hline 8 Sep & $M$ & 0.96 & 13 & 38.2 \\
\hline $8 \mathrm{Sep}$ & $M$ & 1.70 & 14 & 30.6 \\
\hline $8 \mathrm{Sep}$ & $\mathrm{F}$ & 3.55 & 16 & 42.3 \\
\hline 8 Sep & $\mathrm{F}$ & 0.88 & 17 & 41.1 \\
\hline 19 Oct & $\mathrm{M}$ & 1.70 & 9 & 34.8 \\
\hline 19 Oct & $M$ & 1.26 & 11 & 25.8 \\
\hline $19 \mathrm{Oct}$ & $\mathrm{F}$ & 1.59 & 7 & 32.1 \\
\hline $6 \mathrm{Dec}$ & $M$ & 1.20 & 11 & 33.2 \\
\hline $6 \mathrm{Dec}$ & $M$ & 0.77 & 13 & 37.7 \\
\hline $6 \mathrm{Dec}$ & $M$ & 1.57 & 12 & 43.2 \\
\hline $6 \mathrm{Dec}$ & $M$ & 0.81 & 11 & 61.7 \\
\hline $6 \mathrm{Dec}$ & $\mathrm{M}$ & 0.88 & 11 & 46.5 \\
\hline $6 \mathrm{Dec}$ & $F$ & 0.91 & 9 & 23.5 \\
\hline $6 \mathrm{Dec}$ & $\mathrm{F}$ & 0.48 & 9 & 39.9 \\
\hline $6 \mathrm{Dec}$ & $\mathrm{F}$ & 0.81 & 8 & 38.4 \\
\hline $6 \mathrm{Dec}$ & $\mathrm{F}$ & 0.78 & 9 & 38.8 \\
\hline
\end{tabular}

weight regions of the column elution volume in both the cod plasma (Fig. 11A) and the cod endolymph (Fig. 11B). The plasma, however, showed an additional calcium binding fraction of high molecular weight, presumably the yolk precursor vitellogenin.

\section{DISCUSSION}

The data on blood plasma, endolymph and otolith composition indicate that, while there is a fair degree of interaction among these body components, these rela- tionships are not necessarily simple or straightforward The data, however, do present clear evidence of the influence of season on the composition of blood plasma and endolymph and indicate that a major influence on the composition of these body constituents is the development of the gonads before spawning.

\section{Plasma and endolymph metabolites}

Variations in plasma glucose are considered difficult to measure in wild fishes because of the effects of stress and exertion, in relation to capture, on levels of plasma glucose (Chavin \& Young 1970, Wardle 1972, White \& Fletcher 1985). Black et al. (1960) found that exercise did not have a significant effect on blood glucose levels in wild rainbow trout Oncorhynchus mykiss. Unfortunately, Wardle (1972) considered the elevated glucose levels after capture as stress-related alone, and he related these data to 'unstressed' fish that were maintained unfed while in captivity. He did not consider the relative glucose levels of fish in the fed and unfed state. In addition to capture-related stress, it is important to consider environmental stress (Wedemeyer 1981), temperature (Umminger 1969), sex, size, age, reproductive condition (Chavin \& Young 1970, Leach \& Taylor 1977) and the time since last feeding. The ingestion of carbohydrates causes an increase in plasma glucose (Lehninger 1975); this effect is clearly illustrated in research on the sand dab Limanda limanda (Fletcher 1984).

The large number of variables affecting plasma glucose make it difficult, in this case, to determine how representative the glucose data are of normal glucose levels in undisturbed cod in the wild. Wardle (1972) estimated normal blood glucose levels in adult plaice Pleuronectes platessa as 0.8 to $1.4 \mathrm{mM} \mathrm{l}^{-1}$, and White \& Fletcher (1985) found levels varied seasonally from about 0.8 to $2.0 \mathrm{mM} \mathrm{I}^{-1}$ for the same species. Fletcher (1984) found that plasma glucose levels remained between 1.1 and $1.4 \mathrm{mM} \mathrm{l}^{-1}$ and did not vary seasonally

Table 6. Pseudophycis barbatus. Multiple linear regiession model coefficients and associated statistics for estimation of endolymph Sr $\left(\mathrm{mM}^{-1}\right)$ in female cod. Unlike the model presented in Table 4 , blood protein data are included in this model

\begin{tabular}{llll|}
\hline Variable & Coefficient & SE & $p$ \\
\hline Females $(n=12)$ & & & $<0.0001$ \\
Albumin/globulin ratio & 0.001 & $9.44 \times 10^{-5}$ & $<0.0001$ \\
Total plasma protein & $4.08 \times 10^{-5}$ & $8.79 \times 10^{-6}$ & $<0.0001$ \\
Fish length & -0.00027 & $4.99 \times 10^{-5}$ & $<0.01$ \\
Fish weight & $1.35 \times 10^{-6}$ & $5.78 \times 10^{-7}$ & $<0.0001$ \\
GSI & 0.001 & $3.52 \times 10^{-5}$ & $<0.0001$ \\
Plasma Sr & 0.08 & 0.022 & \\
Constant (a) & 0.01 & & \\
Multiple correlation, $\mathrm{R}=0.992$ & & & \\
\hline
\end{tabular}



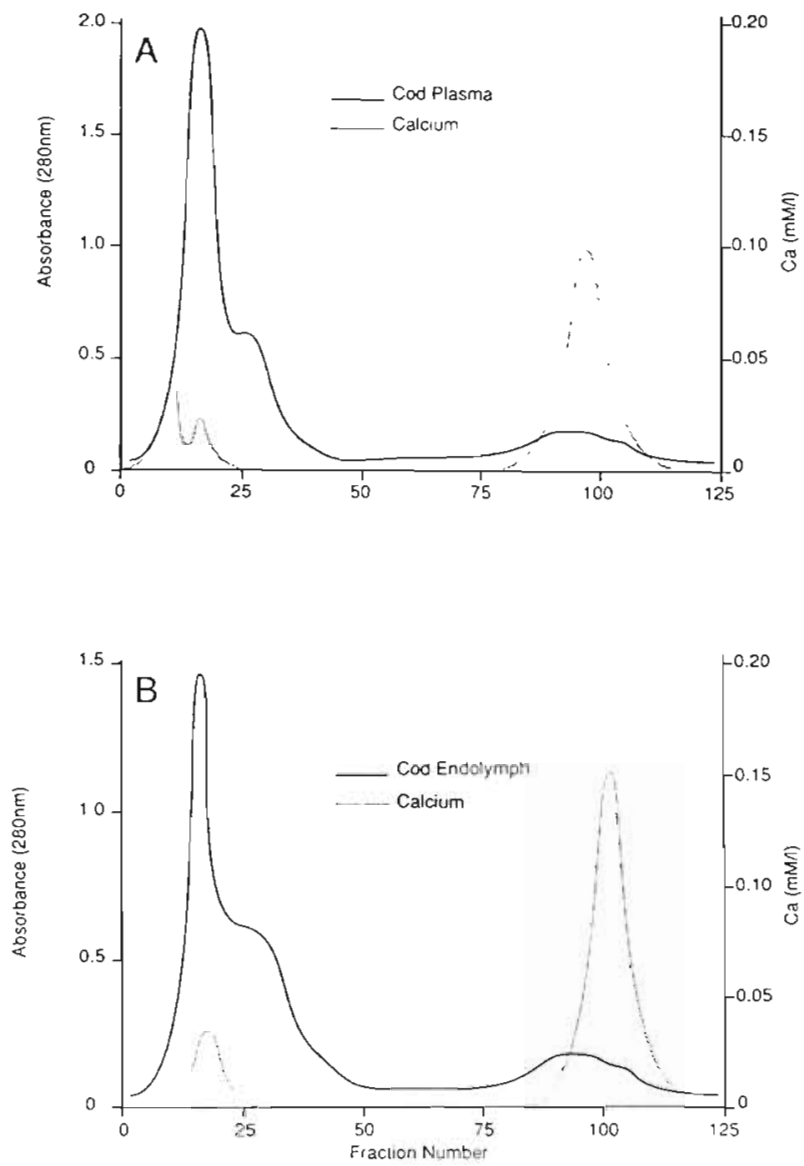

Fig. 11. Pseudophycis barbatus. Column chromatography (Sephadex G-100 Fine) of plasma and endolymph and associated $\mathrm{Ca}$ analyses of the individual fractions. (A) Plasma from an individual female $(48 \mathrm{~cm} \mathrm{SL} ; 2160 \mathrm{~g} ; 2.8 \mathrm{GSI})$ collected from Variety Bay in December. The first Ca peak (fractions 10 to 12) may be associated with vitellogenin. The large Ca peak is free $\mathrm{Ca}$ or $\mathrm{Ca}$ bound to small molecules. (B) Endolymph pooled from 5 cod collected in Variety Bay in December The first $\mathrm{Ca}$ peak is associated with a protein with a molecular weight between $50 \mathrm{~K}$ and $100 \mathrm{~K}$, probably albumin. The large

$\mathrm{Ca}$ peak is free $\mathrm{Ca}$ or $\mathrm{Ca}$ bound to small molecules

in Limanda limanda. In each of these 2 studies the blood glucose levels were measured in fish which had been maintained in captivity without feeding for at least 1 wk. Fletcher (1984) found that feeding dramatically increased plasma glucose in Limanda limanda to more than $6.4 \mathrm{mM} \mathrm{l}^{-1}$ in summer and $3.4 \mathrm{mM} \mathrm{l}^{-1}$ in winter The effects of feeding were evident almost immediately and the plasma glucose levels remained elevated for up to $50 \mathrm{~h}$. Bergot (1979) found that plasma glucose levels reached their peak in rainbow trout $6 \mathrm{~h}$ after a glucose-enriched meal. Because the majority of the cod used in this study were collected between 11:00 and 14:00 h, ca 5 to $8 \mathrm{~h}$ after first light, when feeding probably commences, high plasma glucose levels would be expected. Therefore, it would be unreasonable to estimate the effects of stress on the cod collected in this study on the basis of unfed fish maintained in captivity. On the basis of the studies cited above, it is difficult to determine if the mean plasma glucose level of $3.9 \pm 1.7 \mathrm{mM} \mathrm{l}^{-1}$ measured in cod is indicative of natural levels or the result of stress.

Measurements of total phosphate are not likely to be affected by the immediate effects of capture-related stress, and thus provide information that can be readily related to the physiological state of the fish. However, interpretation of data on total phosphate can be subject to difficulties due to the numerous potential sources of phosphate in the blood. In fish, phosphates can be associated with various phospholipids which are most important as constituents of cell membranes and organelles and are probably the most concentrated lipids in fish plasma (Robinson \& Mead 1973). Phosphate-bearing compounds that can be found in fish plasma include numerous phosphorylated compounds relevant to energy transfer and phospholipoproteins such as vitellogenin which are involved in the process of egg formation and may be precursors of the egg yolk proteins, phosvitin and lipovitellin. It must be understood that levels of inorganic phosphate were measured in this study but that these values are generally altered on the basis of the presence of breakdown products associated with the decomposition of organic compounds present in the blood (Gross 1976, Craik \& Harvey 1984a).

The fact that there were significant differences, both seasonally and on the basis of the interaction of season and sex, is a good indication that, in part, seasonal variations in phosphate were attributable to the presence of a phospholipoprotein such as vitellogenin. This conclusion is supported by the September peak in phosphate in female cod that coincided with the peak in gonadosomatic index. Similar results were also obtained by Petersen \& Emmersen (1977) who found increased serum phospholipid levels in flounder Platichthys flesus at the onset of seasonal ovarian development and through the spawning period. McCartney (1967) found that serum phospholipid levels increased in rainbow trout just prior to and during spawning and, therefore, could not conclude that the changes in phospholipids were directly related to the development of the ovaries.

White et al. (1986) found no clear pattern in plaice serum phospholipids and concluded that these levels were unaffected by ovarian development in this species, although their data do show a peak in serum phospholipid in February that could be related to gonadal development before the February-March spawning period. They obtained mean phospholipid levels in February of $363 \pm 12 \mathrm{mg} 100 \mathrm{ml}^{-1}$ for female plaice and $329 \pm 19 \mathrm{mg} 100 \mathrm{ml}^{-1}$ for males and found no 
significant differences between female and male phospholipid levels throughout the year. Therefore, they concluded that the proteins involved in ovarian development, such as vitellogenin, were not affecting their values. Although it is not totally clear, it appears that White et al. (1986) tested for significant differences in serum lipids between sexes and months separately by 1 -way analysis of variance and did not consider the potential interaction between month and sex by using a 2 -way design. On the basis of the mean values for male and female serum phospholipids in February it seems probable that such an interaction exists as in female bearded rock cod.

The sharp drop in female cod plasma phosphate levels from the September maximum to a December minimum, well below phosphate levels measured in males, indicates that these variations are sex-related and, presumably, related to the spawning cycle. Fletcher (1984) and White et al. (1986) obtained the opposite result, and attributed increases in plasma phospholipids after spawning in Limanda limanda and Pleuronectes platessa to the reabsorption of ovarian material which is predominantly lipid, specifically phospholipid.

In female cod, the low levels of plasma phosphate may be related to the rebuilding of body tissues and reserves after the draining period of gonadal development leading up to spawning. This interpretation would be consistent with data presented by Craik \& Harvey (1984b) which considered seasonal changes in plasma phosphate associated with the development of eggs.

Levels of lipid in the plasma can vary in response to gonadal development, as just discussed, or to levels of feeding. Lipids, primarily in the form of triglycerides stored in the liver, are mobilized during periods of starvation (Lehninger 1975). In 'fatty' fish species interstitial fat in the muscle tissue may also serve as a storage site for triglycerides (Larsson \& Fänge 1977, Fletcher 1984, White et al. 1986), but it is only in times of extreme deprivation that cell constituents such as the phospholipids are broken down for use as an energy source (Lech 1970).

The marked similarity between seasonal cycles of plasma phosphate and triglyceride levels in female cod and the correlation between these variables (females only, $\mathrm{r}^{2}=0.34, \mathrm{n}=54, \mathrm{p}<0.0001$ ) was an additional indication of the dominance of spawning in controlling metabolite levels in the blood plasma. Furthermore, there was a strong positive correlation between the gonadosomatic index and plasma triglyceride levels in the females (females only, $\mathrm{r}^{2}=0.42, \mathrm{n}=54, \mathrm{p}<0.0001$ ) and both data sets show evidence of similar seasonal cycles. These relationships were not evident in the male cod (males only, $r^{2}=0.02, n=61, p>0.05$ ). Ele- vated triglyceride levels in the plasma are indicative of periods of stress due to starvation or the need to satisfy energy requirements that cannot be met by ingested food alone. Mobilization of triglycerides stored in the liver may be the principle source of energy after tissue and liver glycogen reserves are utilized, although the function of these storage molecules may vary to some degree for different species (Lech 1970, White et al. 1986). Triglycerides released into the blood from the liver are hydrolyzed by various lipases resulting in free fatty acids (FFA) and glycerol. The glycerol is ultimately converted to glucose for energy, whereas the FFA may be used to produce energy through the fatty acid oxidation cycle or, alternatively, they can be utilized in the production of plasma lipoproteins such as the egg yolk precursor, vitellogenin (Lech 1970). Therefore, increased levels of plasma triglycerides may occur in response to the females' need to meet energy requirements during the buildup of the gonads before spawning and may also provide material necessary for the production of egg yolk.

The fall in plasma triglycerides in females after the spawning related peak in September was almost identical to that found for phosphates and suggests that, in the second half of the year at least, the triglycerides and phosphate levels were very closely linked. In these circumstances, it seems reasonable to conclude the 2 metabolites were, ultimately, portions of the same phospholipoproteins involved in egg production and that the decreases in phosphate and triglyceride in the spring were due to the need for females to rebuild their body tissues and liver triglyceride stores before the next spawning season. Presumably these constituents were near exhaustion from the stress of gonad produc. tion and spawning.

Endolymph glucose, phosphate and triglyceride levels were clearly affected by the seasonal cycle of spawning in the females. These data were more convincing in this respect than the data from plasma. Peaks in levels of glucose, phosphate and triglyceride in the female endolymph corresponded with the peak in gonadosomatic index in September. There was little variation during the remander of the year and the levels were relatively constant in the males. These data indicate that readiness for spawning may be more easily determined on the basis of metabolites measured in the endolymph rather than in the plasma.

\section{Ions in plasma, endolymph and otoliths}

Seasonal cycles in plasma calcium have been described for many marine and freshwater species. Increases in plasma calcium have been attributed to the development of the female gonads in Salvelinus 
fontinalis (Booke 1964), Carassius auratus (Oguri \& Takada 1967), Gadus morhua (Woodhead 1968), Oncorhynchus mykiss (Whitehead et al. 1980) and many others. Spawning related increases in male plasma calcium were not detected in some cases (Booke 1964, Oguri \& Takada 1967) or levels of plasma calcium were considered to be lower than those measured in the females (Woodhead 1968). Data on bearded rock cod indicate that both males and females became hypercalcemic during the spawning season, however, in all months except July, male cod had significantly lower levels of plasma calcium than females with annual mean values of $1.70 \pm 0.65 \mathrm{mM} \mathrm{I}^{-1}$ and $1.91 \pm$ $0.55 \mathrm{mM} \mathrm{l}^{-1}$, respectively.

Unlike the plasma calcium data, only the female endolymph calcium data showed evidence for a relationship with gonadosomatic index (females only, $r^{2}=0.28, \quad n=54, \quad p<0.001 ;$ males only, $r^{2}=0.003$, $n=61, p \gg 0.50)$. This is not surprising in view of the fact that only the female endolymph showed spawning related increases in glucose, phosphate and triglycerides. Mugiya (1966b) found seasonal changes in endolymph calcium in Oncorhynchus mykiss and a flatfish Kareius bicoloratus, but he did not separate males and females. Therefore, the variations that he discusses may be misrepresentations of the endolymph calcium variations in each sex. Mugiya (1966b) still found a relationship between the seasonal variations in serum and endolymph calcium. Mugiya (1966b) separately measured total and diffusible calcium in both the serum and endolymph and found that the diffusible calcium in the serum more closely reflected the seasonal variations in endolymph calcium. Furthermore, the quantities of diffusible calcium he measured in the serum were very similar to the total amount of calcium found in the endolymph, and thus he concluded that the seasonal variation in total endolymph calcium was related to the change in the quantity of plasma proteins which, in turn, has been shown to be directly related to the relative proportions of bound and diffusible calcium in some organisms.

Over the 12 mo of his study, Mugiya (1966b) found that the total calcium measured in the endolymph was $65.6 \%$ and $66.7 \%$ of the total calcium measured in the blood serum in Kareius bicoloratus and Oncorhynchus mykiss, and that these percentages corresponded with the proportion of diffusible calcium (ionized and complex-bound) to total calcium in the plasma. Similar results were obtained in this study, with female cod endolymph containing $65.5 \%$ and male endolymph containing $73.7 \%$ of the total quantity of calcium measured in the blood plasma. Andreasen (1985) investigated variations in the free (ionized) and total calcium concentrations in the blood plasma of 0 . mykiss and found a very strong correlation $\left(r^{2}=0.99\right)$ between these 2 forms of calcium with $67 \%$ of the total calcium being in the ionized form. These results provide evidence of the significance of levels of plasma proteins in mediating the levels of calcium in fish endolymph. Data on human plasma indicate that $38 \%$ of plasma calcium is in the protein-bound form and $62 \%$ is diffusible, that is, ionized or complexbound calcium (Sena \& Bowers 1988). These data indicate that general principles applicable to the proportions of free and bound calcium in human plasma and serum may be applicable to studies of fish plasma and serum. Furthermore, the fact that a greater percentage of the total plasma calcium occurs in the endolymph in males was indicative of higher levels of calcium-binding proteins in the female plasma. During the winter period of gonadal development female plasma protein levels were consistently greater than in males. It was likely that these increased plasma protein levels and the concomitant reduction in the relative proportion of calcium in the endolymph were attributable to the calcium-binding egg yolk precursor protein, vitellogenin

Seasonal variations in the distribution of calcium and strontium in cod plasma and endolymph were different; however a notable similarity between these data was the September peak in both endolymph strontium and calcium in the females. This was probably related to development of the ovaries. Evidence for interaction between calcium and strontium was provided by multiple regression analysis (Table 3 ). The basis for these relationships was probably due to the total quantity of calcium-binding protein present and the relative discrimination of these proteins in binding $\mathrm{Ca}^{2+}$ over $\mathrm{Sr}^{2+}$. Taking these points into account, an increase in plasma protein in the females as vitellogenin, and an associated increase in plasma calcium, would be expected to result in an increase in the relative proportion of protein-bound calcium in the plasma and an associated reduction in the percentage of the total plasma calcium measured in the endolymph. In female cod there was an increase in total plasma calcium during the period of gonad development from ca 1.5 to $2.3 \mathrm{mM} \mathrm{l}^{-1}$, whereas endolymph calcium increased from 1.3 to $1.7 \mathrm{mM} \mathrm{l}^{-1}$. an increase of exactly half that estimated in the plasma. This indicates that, to a large extent, the increase in plasma calcium in females was due to calcium in the protein-bound form. This conclusion is supported by information presented in Simkiss (1974).

Seasonal increases in male cod plasma calcium were greater than in females and mean monthly values ranged from 1.2 to $2.3 \mathrm{mMl}^{-1}$, yet there were no significant changes in endolymph calcium that could be related to spawning. This indicates that there are factors, in addition to proteins related to gonad develop- 
ment, that are affecting the quantities of $\mathrm{Ca}^{2+}$ and $\mathrm{Sr}^{2+}$ in the plasma and, ultimately, the endolymph.

Because of the similar physical properties of $\mathrm{Ca}^{2+}$ and $\mathrm{Sr}^{2+}$, it might be expected that the variations in the 2 ions would be similar, but this was not the case. In female cod plasma mean monthly strontium values ranged from 8.1 to $17.2 \mu \mathrm{M} \mathrm{l}^{-1}$, while in the endolymph the range was from 1.8 to $7.4 \mu \mathrm{M} \mathrm{l}^{-1}$. Unlike for calcium, the strontium levels in the plasma and the endolymph did not overlap and, while the relative variation in plasma calcium and plasma strontium values were similar, the maximum endolymph strontium values were more than 4 times the minimum value compared with a $30 \%$ increase in endolymph calcium. These differences may be attributable to the relative discrimination against strontium by calcium-binding proteins. Therefore, increases in plasma calcium and strontium due to similar physiological needs, such as gonad development, are reflected in the plasma in a proportional manner. Increases in endolymph calcium and strontium are not comparable because the endolymph component of these ions is, most likely, a function of the amount of calcium-binding protein and thus the proportion of protein-bound to diffusible calcium and strontium in the plasma. This in turn is due to the fact that calcium-binding proteins selectively bind calcium over strontium. The degree of discrimination between these jons will vary from protein to protein and will, of course, be dependent on other characteristics of the plasma such as $\mathrm{pH}$ and the quantities of other ions present. The data on female cod plasma indicated that a $9.1 \mu \mathrm{M} \mathrm{I}^{-1}$ increase in plasma strontium corresponded to a $5.6 \mu \mathrm{M} \mathrm{I}^{-1}$ increase in endolymph strontium, compared with a $0.8 \mathrm{mM} \mathrm{l}^{-1}$ increase in plasma calcium and a $0.4 \mathrm{mM} \mathrm{l}^{-1}$ increase in endolymph calcium. This may be an indication that $50 \%$ of the increased calcium and $38 \%$ of the increased strontium in the plasma is in the protein-bound form and provides additional evidence for discrimination against strontium in preference for calcium.

The major deviation from the linear relationship between plasma strontium and endolymph strontium (Fig. 6) was attributable to 5 fish with endolymph strontium levels in excess of $8 \mu \mathrm{M} \mathrm{I}^{-1}$. These high endolymph strontium levels were associated with individuals with a high GSI, specifically 4 females and 1 male. Relationships involving levels of endolymph and plasma phosphate, glucose and triglycerides serve to further identify the physiological condition of these individuals in spawning condition. The highest $\mathrm{Sr} / \mathrm{Ca}$ ratios measured in the otoliths of blue grenadier were from 3 female fish (Kalish 1989), each with relatively high GSIs and, as in the cod, this was probably indicative of a high endolymph $\mathrm{Sr} / \mathrm{Ca}$ ratio that can be associated with gonad development.
Increases in endolymph strontium were significantly related to increases in plasma protein, but it is likely that this relationship was due, not to increases in plasma protein in general, but to increases in specific plasma proteins. For this reason a preliminary investigation was made into the seasonal variations in plasma proteins to determine if there were significant changes over the year and among individuals. The data indicate very significant changes in the levels of the major plasma protein components, specifically globulins and albumin. Albumin, besides acting in osmotic regulation and the transport of other plasma constituents, is the major calcium-binding protein present in blood plasma (Lehninger 1975). The large variations in albumin could have a very significant impact on the relative proportions of diffusible and non-diffusible calcium present in the plasma and, ultimately, the composition of the endolymph

Radtke (1989), Radtke \& Morales-Nin (1989), and Townsend et al. (1989) attempted to explain variations in otolith $\mathrm{Sr} / \mathrm{Ca}$ ratios in terms of temperature and apply otolith-derived temperature records to investigations of distribution and recruitment. Interpretation of otolith $\mathrm{Sr} / \mathrm{Ca}$ ratio data on the basis of temperature alone may be an oversimplification of the mechanism that results in variations in otolith $\mathrm{Sr} / \mathrm{Ca}$ ratios. I have demonstrated a negative correlation between temperature and both plasma strontium and endolymph strontium. On this basis, it seems that physiological changes are resulting in changes in the level of strontium in both the plasma, the endolymph and, ultimately the otolith. The temperature-related changes in plasma strontium, in the case of adult bearded rock cod, were probably associated with gonadal development and, thus, can be related to changes in plasma calcium. The relationship between endolymph strontium and temperature was probably a further manifestation of the physiological changes associated with reproduction and the related changes in the plasma protein complement.

Attempts to explain distributional changes of juvenile Atlantic bluefin tuna Thunnus thynnus thynnus based on an assumed relationship between otolith $\mathrm{Sr} / \mathrm{Ca}$ ratios and temperature (Radtke \& Morales-Nin 1989) are not well founded. It is likely that individual bluefin tuna experience a range of physiological changes that result in variations in both endolymph and otolith composition. Changes in otolith $\mathrm{Sr} / \mathrm{Ca}$ ratios are probably similar among individuals due to common genetic programming and environmental conditions. Furthermore, because tuna maintain muscle, eye and brain temperatures significantly above ambient temperatures (Stevens \& Fry 1971, Linthicum \& Carey 1972), the otoliths may experience elevated temperatures as well. Evidence that otoliths are main- 
tained at elevated temperatures is provided by oxygen stable isotope data in Radtke et al. (1987) and Kalish (in press, a). Both Radtke et al. (1987) and Kalish (in press, a) show that oxygen isotopes in Atlantic bluefin and southern bluefin tuna Thunnus maccoyil are not deposited in equilibrium with ambient water temperature, but are affected by the elevated body temperature of these fishes. Body temperatures are not necessarily constant, but in Atlantic bluefin tuna, fluctuations are small relative to ambient temperatures (Carey \& Lawson 1973). The combined effects of body temperature regulation and physiologically based changes in endolymph composition in bluefin tuna make the accurate interpretation of otolith Sr/Ca ratios in terms of ambient water temperature unlikely.

Changes in the endolymph composition associated with adult fish during gonad development cannot be used to explain changes in otolith $\mathrm{Sr} / \mathrm{Ca}$ ratios measured in larvae and juveniles as measured by Radtke (1989) and Townsend et al. (1989); however, a calciumbinding protein mechanism can also be operating in the larvae and juveniles. Changes in growth rate, age, physiology and health can affect the protein complement of fish. The exact nature of these changes is beyond the scope of this study but, in some instances, it is possible to gain an insight into the mechanisms involved. For example, Townsend et al. (1989) hypothesized that their laboratory-based calibration of $\mathrm{Sr} / \mathrm{Ca}$ ratio versus temperature (their Fig. 6A) could not be applied to Sr/Ca ratios measured in wild fish because of the effects of stress on the $\mathrm{Sr} / \mathrm{Ca}$ ratios of laboratory fish. They postulate that stress reduced the ability of the fish to discriminate physiologically between calcium and strontium. Two Australian salmon Arripis trutta in a $\mathrm{Sr} / \mathrm{Ca}$ ratio validation study (Kalish 1989) were stressed with fin rot and had relatively low condition factors. These individuals also had the highest mean otolith $\mathrm{Sr} / \mathrm{Ca}$ ratios (0.0034) of any of the captive Australian salmon. I also found consistent evidence for increased Sr/Ca ratios in stressed, wild juvenile Australian salmon stranded in a lagoon (Kalish unpubl.). Although the 'stressed' fish in Townsend et al. (1989) had higher otolith $\mathrm{Sr} / \mathrm{Ca}$ ratios than they expected, these ratios were still lower than those measured in other, supposedly unstressed, individuals reared at lower temperatures. In this instance, the moderate effect of stress would make it very difficult to distinguish variations in ambient temperature from varying levels of stress. Nevertheless, stress may change the protein complement and ultimately affect the relative proportions of calcium and strontium in the endolymph.

An alternate hypothesis for changes in otolith $\mathrm{Sr} / \mathrm{Ca}$ ratios in larvae involves changes in the ability to osmoregulate with increasing size. The movement of ions into the blood may be relatively unregulated in larvae and small juveniles with the ions present more closely resembling seawater. This may be a function of differences in ion regulation by the gills and the integument, which, at this early stage, lacks scales. As the fish develops there may be increased discrimination between calcium and strontium by the gills and the integument. Because many fish species show relatively high otolith Sr/Ca ratios during the larval period followed by reduced levels after metamorphosis (Kalish unpubl.), it may be that these changes are more related to physiology than habitat temperature. Although similar changes in otolith $\mathrm{Sr} / \mathrm{Ca}$ ratios have been found in the progeny of anadromous salmonids, these variations are related to the composition of yolk contributed by the female parent (Kalish 1990)

Although there is clearly a relationship between the quantity of strontium in the endolymph and the otolith (Fig. 9), the correlation between the 2 data sets is not as good as had been anticipated. As is indicated below in the discussion of the results of the linear multiple regression models, the interaction of several variables may ultimately play a part. Also, it is important to indicate the difficulties that arise when using measurements of the outer otolith margin composition as an indicator of the composition of the most recently formed portions of the otolith. Because of sample destruction during electron microprobe analysis of readily vaporized minerals such as carbonates, it is necessary to use a scanning raster or a defocussed electron beam. Ideally, the minimum size for a square window that would minimize sample destruction is $10 \times 10 \mu \mathrm{m}$. In the fast-growing juvenile Arripis trutta used in another study (Kalish 1989), there is clearly more than $10 \mu \mathrm{m}$ of recently formed otolith material available for analysis. But in the slow-growing adult cod, 10 um of otolith material may encompass aragonite deposited in the last several months, particularly in the winter periods when the growth rate would be lowest. The result is the comparison of a temporally discrete endolymph sample with an integrated sample of otolith composition, not an ideal situation.

The results of the linear multiple regression models, while of little practical use in actual prediction, provide a valuable insight into those factors that ultimately influence the strontium content of both fish endolymph and otoliths. Most importantly, in view of the present interest in fish otoliths as predictors of environmental temperature, is the fact that the variable ambient temperature was the first variable selected in models to predict the strontium content of fish endolymph (Table 3). Furthermore, temperature does not appear as a variable in any of the multiple regression models to predict otolith strontium (Table 4). This illustrates that, in the otoliths of adult bearded rock cod at least, tem- 
perature does not appear to directly influence the strontium content of fish otoliths. Alternatively, as hypothesized on the basis of data presented in Kalish (1989), the effect of temperature or, perhaps more generally, the effect of seasonal changes in physiology which are associated with changes in temperature, are the primary force in altering the composition of fish endolymph and, concomitantly, fish otoliths. This conclusion is highlighted by the relationship that also exists between the strontium content of blood plasma and endolymph, evident in both male and female fish.

This study and an earlier investigation on blue grenadier (Kalish 1989) both considered otolith composition of mature adult fish that spawn during the coldest winter months, and, thus, it is plausible that the occurrence of peak otolith strontium levels in winter is largely associated with the physiological changes related to gonad development. This hypothesis is supported, in part, by the occurrence of peak otolith strontium levels measured in the summer and fall in juvenile Australian salmon; however, the presence of a definable peak at any time of the year in juvenile fish clearly implicates the importance of factors other than reproduction in the contral of otolith microchemistry Gonadosomatic index was the second most important variable in the prediction of endolymph and otolith strontium in female cod, whereas neither GSI nor gonad weight was used to predict the dependent variable in male cod. In view of these results it would be important to investigate variations in endolymph and otolith composition in a species that spawned in the summer.

The distribution coefficient $K_{S r}$, defined by

$$
\left(\frac{\mathrm{Me}}{\mathrm{Ca}}\right)_{\mathrm{CaCO}_{3}}=K_{\mathrm{Me}}\left(\frac{\mathrm{Me}}{\mathrm{Ca}}\right)_{\text {solution }}
$$

where Me and Ca refer to molar concentrations of the trace metal and calcium present in the solid phase calcium carbonate and in the precipitating solution, found for the bearded rock cod was significantly different from that found in Kalish (1989) based on a wide range of fish species (Fig. 12). The distribution coefficient, $K_{\text {SI }}$ for the cod data only is $0.146 \pm 0.31$ compared with $0.255 \pm 0.052$ for the multi-species estimate. The 2 slopes were compared and were found to be significantly different ( $t=25.6, \mathrm{df}=152, \mathrm{p}<0.0001$ ) ; however, inspection of the mixed species data (Fig 12) (Kalish 1989) shows that the discrepancy results from 4 data points, attributable to freshwater Salmo trutta (the only non-marine species in the relationship), with very low otolith Sr/Ca ratios. Removal of the $S$. trutta data results in a $K_{\mathrm{Sr}}$ of $0.181 \pm 0.038$ which is not significantly different from the bearded rock cod $K_{\mathrm{Sr}}$. These results indicate that the precipitation of endolymph $\mathrm{Sr} / \mathrm{Ca}$ to form the otolith is probably dominated by similar prop-

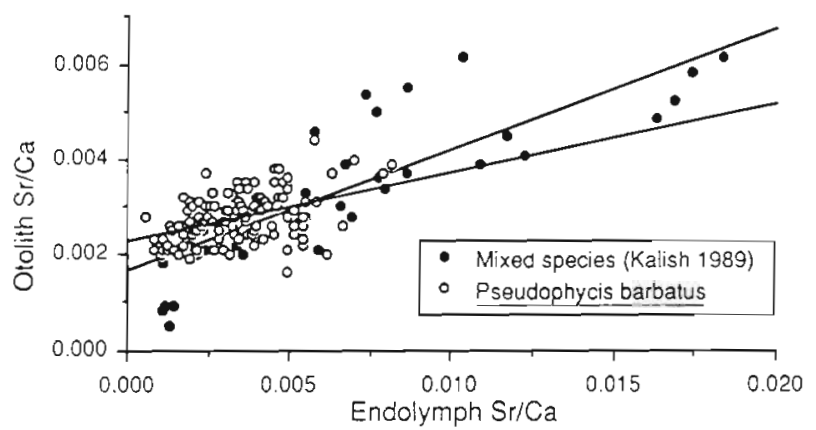

Fig. 12. Comparison of the relationship between otolith $\mathrm{Sr} / \mathrm{Ca}$ and endolymph Sr/Ca for the Pseudophycis barbatus data and similar data from several species collected in an earlier study (Kalish 1989). The line for the cod data is described by the equation $O_{S r}=0.0023+0.1456\left(E_{S r}\right),\left(r^{2}=0.19, p<0.001\right.$, $\mathrm{n}=115)$ and for the mixed species data the line is described by $\mathrm{O}_{\mathrm{St}}=0.0018+0.2453\left(\mathrm{E}_{\mathrm{Sr}}\right),\left(\mathrm{r}^{2}=0.82, \mathrm{p}<0.0001, \mathrm{n}=44\right)$. The slopes of the 2 lines are significantly different $(t=25.6$, $\mathrm{df}=152, \mathrm{p}<0.001)$; however, the slopes are not significantly different if the 4 points with the lowest otolith Sr/Ca ratios

(attributable to freshwater Salmo trutta) are removed

erties in all species considered. In both cases the values for $K_{\mathrm{S}}$ are low when compared with data obtained from corals and some bivalves which have $K_{\mathrm{Sr}}$ values of ca 1.0. This point is discussed briefly in Kalish (1989).

Low $K_{\mathrm{Sr}}$ values for fish otoliths in general may be due, in part, to the potential effect of precipitation rate on trace element incorporation. Unfortunately, few studies have considered the effect of aragonite or calcite precipitation rate in inorganic systems, let alone in biogenic carbonates. It is generally accepted that precipitation can play a major role in determining distribution coefficients (Ohara \& Reid 1973), and, even in investigations of inorganic precipitates, inter-study differences in distribution coefficients are attributed to differences in the rate of precipitate formation (Okumura \& Kitano 1986). Lorens (1981) investigated the effect of precipitation rate on the incorporation of $\mathrm{Sr}, \mathrm{Cd}, \mathrm{Mn}$ and $\mathrm{Co}$ in calcite. His data indicated that $K_{\mathrm{Sr}}$ increased with increasing precipitation rate, whereas $K_{\mathrm{Cd}}, K_{\mathrm{Mn}}$ and $K_{\mathrm{Co}}$ decreased with increasing precipitation rate.

The partial dependence of the distribution coefficient on crystal growth rate is based on the interaction between metal ions and the morphologically variable crystal surface (Kinsman \& Holland 1969. Lorens 1981. Morse 1983). The crystal surface is heterogeneous in terms of morphology, and thus includes sites of different energies (Burton et al. 1951). During crystal growth cations become incorporated in these sites and with further crystal growth the coordination of the cation increases until it is a fully coordinated component of the crystal lattice. The amount of time required for full coordination of a particular cation site will vary depending on the initial degree of coordination of the 
site. At slow crystal growth rates all cation sites would have adequate time to reach equilibrium with the precipitating solution, and, in these instances, the resulting distribution coefficient would be near the value expected for an equilibrium distribution coefficient Alternatively, if crystal growth were proceeding at a very rapid rate, in a similar system with a complex distribution of cation sites with differing coordination, then an individual cation might become incorporated before equilibration, regardless of the initial coordination of the cation site. In these circumstances, the distribution coefficient would be indicative of the level of coordination for which equlibration could be achieved in the time available (Kinsman \& Holland 1969, Lorens 1981). Simply, slow precipitation rates would result in low distribution coefficients indicative of equilibrium between the precipitating solution and the solid, whereas fast rates of precipitation could result in high distribution coefficients that are more an indicator of the initial number of cation sites suitable for the incorporation of a particular cation such as $\mathrm{Sr}^{2+}$.

Precipitation rate relationships as described above may be an important determinant of the distribution coefficient. Although it is difficult to accurately estimate the crystal growth rate of fish otoliths it is probably not unreasonable to conclude that their crystal growth rate is slower than that of coral or molluscan calcium carbonate during comparable growth phases, given the relative ages and sizes of the structures. If this were true, then the slower precipitation rates in fish otoliths may explain the relatively low distribution coefficients for strontium when compared with corals and molluscs.

Data presented here on the composition of blood plasma and endolymph provide insight into the nature of calcium and strontium transport across cell membranes. Generally, vertebrates discriminate between calcium and strontium. This discrimination is mediated by proteins that can selectively bind calcium. Different calcium-binding proteins show varying levels of discrimination. Although this form of discriminatory binding may be occurring in the plasma it does not explain the correspondence between levels of free calcium and strontium in the plasma and the levels of total calcium and strontium measured in the endolymph. In fact, the relationship between these values indicates that a calcium-binding protein may not be involved in the movement of calcium and strontium from the plasma to the endolymph. Otherwise, it would be expected that the $\mathrm{Sr} / \mathrm{Ca}$ ratio in the endolymph would be much less than that measured in the plasma. Therefore, these data provide evidence of paracellular transport of calcium and strontium across the macula of teleost fish. A similar conclusion was reached in a study of calcium transport across the shell gland of domestic fowl (Simkiss et al. 1973). These results are important to the interpretation of studies that consider the calcification of otoliths and mechanisms of calcium transport to the endolymph (Mugiya 1974, 1977, 1986).

Research on oxygen and carbon stable isotopes in fish otoliths provides evidence for both temperature and metabolic effects on otolith composition (Kalish in press, a, b). These data may provide a suitable alternative or adjunct to otolith trace element data. They also indicate that other factors such as metabolic rate and diet may play a significant role in determining otolith trace element chemistry.

This study demonstrates that the interpretation of otolith microchemistry data cannot be based on temperature data alone and thus corroborates hypotheses generated in Kalish (1989). In the case of cod, the negative correlation between temperature and otolith strontium is a fortuitous one, with changes in physiology being the major force. In other species, changes in physiology similar to those observed here are likely to occur at very different times of the year and for a wide range of reasons. Therefore, before the interpretation of otolith microchemistry data is undertaken, the researcher must carefully consider the various environmental and physiological factors unique to each species.

Acknowledgements. Thanks to Wayne Kelly and Richard Holmes of the University of Tasmania for assistance in sample collection, Jim Kiss at the Hobart Repatriation Hospital for assistance with sample analyses, Des Richardson at Austratian Newsprint Mills for the use of analytical facilities and Charles Dragar, Peter Davies and Stephanie Rae for valuable discussion. This study was supported by a University of Tasmania Research Grant.

\section{LITERATURE CITED}

Andreasen, P. (1985). Free and total calcium concentrations in the blood of rainbow trout, Salmo gairdneri, during 'stress' conditions. J. exp. Biol. 118: 111-120

Bergot, F. (1979). Effects of dietary carbohydrates and of their mode of distribution on glycaemia in rainbow trout (Salmo gairdneri, Richardson). Comp. Biochem. Physiol. 64A: 543-547

Black, E. C., Robertson, A. C., Hanslip, A. R., Chiu, W.-G (1960). Alterations in glycogen, glucose and lactate in rainbow and Kamloops trout, Salmo gairdneri, following muscular activity. J. Fish. Res. Bd Can. 17: 487-499

Bondar, R. J. L., Mead, D. C. (1974). Evaluation of glucose-6phosphate dehydrogenase from Leuconostoc mesenteroides in the hexokinase method for determining glucose in serum. Clin. Chem. 20: 586-590

Booke, H. E. (1964). Blood serum protein and calcium levels in yearling brook trout. Prog. Fish-Cult. 26: $107-110$

Bradford, M. M. (1976). A rapid and sensitive method for the quantitation of microgram quantities of protein utilizing the principle of protein-dye binding. Analyt. Biochem. 72: $248-254$ 
Burton, W. K., Cabrera, N., Frank, F. C. (1951). The growth of crystals and the equilibrium structure of their surfaces Phil. Trans. R. Soc. London A243: 299-358

Carey, F. G., Lawson, K. D. (1973). Temperature regulation in free-swimming bluefin tuna. Comp. Biochem. Physiol 44A: $375-392$

Chavin, W. Young, J. E. (1970). Factors in the determination of normal serum glucose levels of goldfish. Carassius auratus L. Comp. Biochem. Physiol. 33: 629-653

Craik, J. C. A.. Harvey, S. M. (1984a). The magnitudes of three phosphorus-containing fractions in the blood plasma and mature eggs of fishes. Comp. Biochem. Physiol. 78B $539-543$

Craik, J. C. A., Harvey, S. M. (1984b). A biochemical method for distinguishing between the sexes of fishes by the presence of yolk protein in the blood. J. Fish Biol. 25: 293-303

Daly, J. A., Ertingshausen, G. (1972). Direct method for determining inorganic phosphate in serum with the centrifiChem' Clin. Chem. 18 (3): 263-265

Doumas, B. T., Watson, W A., Biggs, H. G. (1971). Albumin standards and the measurement of serum albumin with bromcresol green. Clin. Chim. Acta 31:87-96

Draper, N. R., Smith, H. (1981). Applied regression analysis John Wiley and Sons, Inc., New York

Enger, P. S. (1964). Ionic composition of the cranial and labyrinthine fiuids and saccular D. C. potentials in fish. Comp. Biochem. Physiol. 11: 131-137

Fänge, R, Larsson, A., Lidman, U. (1972). Fluıds and jellies of the acusticolateralis system in relation to body fluids in Coryphaenoides rupestris and other fishes. Mar. Biol. 17 : 180-185

Fletcher, D. J. (1984). Plasma glucose and plasma fatty acid levels of Limanda limanda (L.) in relation to season, stress, glucose loads and nutritional state. J. Fish Biol. 25 $629-648$

Gross, H. (1976). Calcium and Phosphatgehalt im Blutserum von Forellen in Beziehung zum Teichchemismus. Fisch $u$. Umwelt 2: 93-109

Hille, S. (1982). A literature review of the blood chemistry of rainbow trout, Salmo gairdneri Rich. J. Fish Biol. 20: 535-569

Kalish, J. M. (1989). Otolith microchemistry: validation of the effects of physiology, age and environment on otolith composition. J. exp. mar. Biol. Ecol. 132: 151-178

Kalish, J. M. (1990). Use of otolith microchemistry to distinguish the progeny of sympatric anadromous and non-anadromous salmonids. Fish. Bull. U.S. 88: 657-666

Kalish, J. M. (in press, a). ${ }^{13} \mathrm{C}$ and ${ }^{18} \mathrm{O}$ isotopic disequilibria in fish otoliths: metabolic and kinetic effects. Mar. Ecol. Prog Ser.

Kalish, J. M. (in press, b). Oxygen and carbon stable isotopes in the otoliths of wild and laboratory maintained Australian salmon (Arripis trutta). Mar. Biol.

Kingsley, G. R. (1939). The determination of serum total protein, albumin, and globulin by the biuret reaction. J. Biol. Chem. 131. 197--200

Kinsman, D. J. J., Holland, H. D. (1969). The co-precipitation of cations with $\mathrm{CaCO}_{3}$-IV The co-precipitation of Sr with aragonite between $16^{\circ}$ and $96^{\circ} \mathrm{C}$. Geochim. Cosmochim. Acta 33: 1-17

Korcock, D. E., Houston, A. H., Gray, J. D. (1988). Effects of sampling conditions on selected blood variables of rainbow trout, Salmo gardneri Richardson. J. Fish. Biol. 33: 319-330

Larsson, A., Fänge, R. (1977). Cholesterol and free fatty acids (FFA) in the blood of marine fish. Comp. Biochem. Physiol. 57B: $191-196$
Leach, G. J., Taylor, M. H. (1977). Seasonal measurements of serum glucose and serum cortisol in a natural population of Fundulus heteroclitus L. Comp. Biochem. Physiol. 56A: $217-223$

Lech, J. J. (1970). Glycerol kinase and glycerol utilization in trout (Salmo gairdneri) liver Comp. Biochem. Physiol. 34: $117-124$

Lehninger, A. L. (1975). Biochemustry, 2nd edn. Worth Publishers, Inc., New York

Linthicum, D. S., Carey, F. G. (1972), Regulation of brain and eye temperatures by the bluefin tuna. Comp. Biochem. Physiol. 43A: 425-433

Lorens, R. B. (1981). Sr, Cd, Mn and Co distribution coefficients in calcite as a function of calcite precipitation rate. Geochim. Cosmochim. Acta 45: 553-561

Lorens, R. B., Bender, M. L. (1980). The impact of solution chemistry on Mytilus edulis calcite and aragonite. Geochim Cosmochim Acta 44: 1265--1.278

McCartney, T. H. (1967). Monthly variations of the serum total cholesterol and serum total lipid-phosphorus of mature brown trout. Fish. Res. Bull. N: Y 30:42-45

Morse, J. W. (1983). The kinetics of calcium carbonate dissolution and precipitation. In: Reeder, R. J. (ed.) Carbonates: mineralogy and chemistry. Mneralogical Society of America, New York, p. 227-264

Mugiya, Y (1964). Calcification in fish and shell-fish III. Seasonal occurrence of a prealbumin fraction in the otolith fluid of some fish, corresponding to the period of opaque zone formation in the otolith. Bull. Jap. Soc. scient. Fish. 30: $955-967$

Mugiya, Y (1966a). Calcification in fish and shell-fish V. A study on paper electrophoretic patterns of the acid mucopolysaccharides and PAS-positive materials in the otolith fluid of some fish. Bull. Jap. Soc. scient. Fish. 32: $117-123$

Mugiya, Y (1966b). Calcification in fish and shell-fish VI. Seasonal change in calcium and magnesium concentrations of the otolith fluid in some fish, with special reference to the zone formation of their otolith. Bull. Jap. Soc. scient. Fish. 32: 549-557

Mugiya, Y (1974). Calcium-45 behavior at the level of the otolithic organs of rainbow trout. Bull. Jap. Soc. scient. Fish. 40: 457-463

Mugiya, Y (1977). Effect of acetazolamide on the otolith growth of goldfish. Bull. Jap. Soc. scient. Fish. 43: 1053-1058

Mugiya, $Y$ (1986). Effects of calmodulin inhibitors and other metabolic modulators on in vitro otolith formation in the rainbow trout, Salmo gairdneri. Comp. Biochem. Physiol. 84 A. 57-60

Mugiya, Y., Takahashi, K. (1985). Chemical properties of the saccular endolymph in the rainbow troul., Salmo gairdneri. Bull. Fac. Fish. Hokkaido Univ 36: 57-63

Oguri, M., Takada, N. (1967). Serum calcium and magnesium levels of goldfish, with special reference to the gonadal maturation. Bull. Jap. Soc. Scient. Fish. 33: 161-166

Ohara, M., Reid, R. C. (1973). Modelling crystal growth rates from solution. Prentice-Hall International Series, New York

Okumura, M., Kitano, Y (1986). Coprecipitatıon of alkalı metal ions with calclum carbonate. Geochim. Cosmochim. Acta 50: 49-58

Petersen, I. M., Emmersen, B. K. (1977). Changes in serum glucose and lipids, and liver glycogen and phosphorylase during vitellogenesis in nature in the flounder (Platichthys flesus, L.). Comp. Blochem. Physiol. 58B: 167-171

Radtke, R. L. (1984). Cod fish otoliths: Information storage 
structures. In: The propagation of cod Gadus morhua L. Flodevigen Rapp. 1: 273-298

Radtke, R. I. (1989). Strontium-calcium concentration ratios in fish otoliths as environmental indicators. Comp. Biochem. Physiol. 92A: 189-193

Radtke, R. L., Morales-Nin, B. (1989). Mediterranean juvenile bluefin tuna: life history patterns. J. Fish Biol. 35: 485-496

Radtke, R. L., Williams, D. F., Hurley, P. C. F. (1987). The stable isotopic composition of bluefin tuna (Thunnus thynnus) otoliths: evidence for physiological regulation. Comp. Biochem. Physiol. 87A: 797-801

Reeder, R. J. (ed.) (1983). Carbonates: mineralogy and chemistry. Reviews in Mineralogy Vol. 11. Mineralogical Society of America, New York

Robinson, J., Mead, J. (1973). Lipid absorption and deposition in rainbow trout (Salmo gairdneri). Can J. Biochem. 51. 1050-1058

Sena, S. F., Bowers, Jr, G. N. (1988). Measurement of ionized calcium in biological fluids: ion-selective electrode method. In: Riordan, J. F., Vallee, B. L. (eds.) Methods in enzymology, Vol. 158. Academic Press, San Diego, p. $320-334$

Simkiss, K. (1974). Calcium metabolism of fish ir relation to ageing. In: Bagenal, T. B. (ed.) Ageing of fish. Unwin Bros. Ltd., London, p. 1-12

Simkiss, K., Hurwitz, S., Bar, A. (1973). ${ }^{85} \mathrm{Sr} /{ }^{45} \mathrm{Ca}$ discrimination by the active shell gland in the fowl. Comp. Biochem. Physiol. 44A: 201-205

Sokal, R. R., Rohlf, F. J. (1981). Biometry, 2nd edn. W H Freeman and Co., San Francisco

Stevens, E. D., Fry, F. E. J. (1971). Brain and muscle temperatures in ocean caught and captive skipjack tuna Comp. Biochem. Physiol. 38A: 203-211

Townsend, D. W., Radtke, R. L., Morrison, M. A, Folsom, S. D. (1989). Recruitment implications of larval herring overwin-

This article was presented by R. L. Haedrich, St. John's, Nfld, Canada tering distributions in the Gulf of Maine inferred using a new otolith technique. Mar Ecol. Prog. Ser. 55: 1-13

Umminger, B. L. (1969). Physiological studies on super-cooled killifish (Fundulus heteroclitus) - I. Serum inorganic constituents in relation to osmotic and ionic regulation at subzero temperature J. exp. Zool. 172: 283-302

Wahlefeld, A. W. (1974). Triglycerides: determination after enzymatic hydrolysis. In: Bergmeyer, H. U. (ed.) Methods of enzymatic analysis, 2nd English edn. Academic Press, New York, p. 1831-1835

Wang, J., Chen, C. C., Osaki, S. (1983). Optimization of the phosphorus-UV reagent. Clin. Chem. 29: 1255

Wardle, C. S. (1972). The changes in blood glucose in Pleuronectes platessa following capture from the wild: a stress reaction. J. mar. biol. Ass. U.K. 52: 635-651

Watanabe, Y., Miyamoto, H. (1973). Biochemical study of labyrinthine fluids (of the fish). Med. J. Osaka Univ. 23: 273-282

Wedemeyer, G. A. (1981). The physiological response of fishes to the stress of intensive aquaculture in recirculating systems. In: Tiews, K. (ed.) Aquaculture in heated effluents and recirculating systems. Heenemann, Berlin, p. 3-18

White, A., Fletcher, T C. (1985). Seasonal changes in serum glucose and condition of the plaice, Pleuronectes platessa L. J. Fish Biol. 26: 755-764

White, A., Fletcher, T. C., Pope, J. A. (1986). Seasonal changes in serum lipid composition of the plaice, Pleuronectes platessa L. J. Fish Biol. 28: 595-606

Whitehead, C., Bromage, N. R., Harbin, R., Matty, A. J. (1980). Oestradiol-17 $\beta$, calcium and vitellogenin interrelationships during accelerated and biannual spawnings in rainbow trout. Gen. comp. Endocrinol. 40: 329-330

Woodhead. P. M. J. (1968). Seasonal changes in the calcium content of the blood of arctic cod. J. mar. biol. Ass. U.K. 48 : $81-91$

Manuscript first received: February 6, 1991

Revised version accepted: May 21, 1991 